\title{
Environmental Covariation of Metazoans and Microbialites in the Lower Ordovician Boat Harbour Formation, Newfoundland
}

\section{Citation}

Pruss, Sara B., and Andrew H. Knoll. 2017. Environmental Covariation of Metazoans and Microbialites in the Lower Ordovician Boat Harbour Formation, Newfoundland.

Palaeogeography, Palaeoclimatology, Palaeoecology 485 (November): 917-929.

\section{Permanent link}

http://nrs.harvard.edu/urn-3:HUL.InstRepos:41291562

\section{Terms of Use}

This article was downloaded from Harvard University's DASH repository, and is made available under the terms and conditions applicable to Open Access Policy Articles, as set forth at http:// nrs.harvard.edu/urn-3:HUL.InstRepos:dash.current.terms-of-use\#OAP

\section{Share Your Story}

The Harvard community has made this article openly available. Please share how this access benefits you. Submit a story.

Accessibility 
1 Environmental Covariation of Metazoans and Microbialites

2

3

4

5

6 aDepartment of Geosciences, Smith College, Northampton, Massachusetts 01063, USA,

$7 \quad{ }^{b}$ Department of Organismic and Evolutionary Biology, Harvard University, Cambridge, in the Lower Ordovician Boat Harbour Formation, Newfoundland

8

17 *Corresponding author. Tel.: +1 4135853948

18 Email Address: spruss@ smith.edu 


\section{ABSTRACT}

An antagonistic view of the relationship between microbialites and metazoans has

22 long been inferred, in part because of the large scale anticorrelation of these two groups

23 through geologic time. The nexus of this relationship occurs in the Early Paleozoic Era:

24 stromatolites declined in abundance as complex animals and algae diversified, but

25 thrombolites, a type of microbialite little known before the Proterozoic-Cambrian

26 boundary, proliferated for the first time. Well-preserved parasequences in the basal

27 portion of the Lower Ordovician Boat Harbour Formation, western Newfoundland,

28 contain a succession of stromatolites and thrombolites that permit an investigation into

29 the role metazoans played in shaping the nature and abundance of microbialites in Early

30 Paleozoic carbonate seas. Sessile benthic animals colonized thrombolite surfaces, but are

31 nearly absent from stromatolites. Bioturbation rarely co-occurred with microbialites, but

32 is widespread in clastic carbonates that lack microbialites. Our results, thus, support the

33 hypothesis of ecological antagonism between microbial communities and motile benthic

34 animals, but also demonstrate biological facilitation between thrombolites and both

35 sessile benthic animals and nekton. 
54 characterized by clotted rather than laminated textures (Aitken, 1967; Kennard and

55 James, 1986). With limited exceptions (e.g., Aitken and Narbonne, 1989; Grotzinger et

56 al., 2000; Harwood and Sumner, 2011), thrombolites are essentially unknown from

57 Proterozoic successions. The global expansion of thrombolites during Cambro-

58 Ordovician time has been noted previously (e.g. Kennard and James, 1986; Riding, 2000;

59 Rowland and Shapiro, 2002; Shapiro and Awramik, 2006) and interpreted in terms that

\section{Introduction}

Conventionally, the geologic record of carbonate rocks is parsed into a long preCambrian interval rich in microbialites but lacking mineralized skeletons followed by a shorter Phanerozoic period in which skeletons dominate carbonate deposition (e.g., Zeebe and Westbroek, 2003). While this view is broadly correct, Ediacaran to Lower

Ordovician carbonates show that the boundary between the two states was a corridor and not a door. Mineralized skeletons first appear during the last eight to nine million years of the Ediacaran Period (Grotzinger et al., 2005), but while skeletons are apparent in most Cambrian and Lower Ordovician carbonate successions, they commonly make only a limited contribution to carbonate sedimentation (Pruss et al., 2010; Pruss et al., 2012; Creveling et al., 2013). In contrast, while tabulations of stromatolite diversity suggest that these structures diminished in importance from the Proterozoic to the Phanerozoic (e.g. Awramik, 1971, 1992; Walter and Heys, 1985; Semikhatov and Raaben, 1996), microbialites are conspicuous features of Cambrian and Lower Ordovician sections worldwide (e.g. Riding, 2005; Peters et al., 2017). A unique aspect of CambroOrdovician microbialites is the abundance of thrombolites, microbial structures vary from a radiation of calcified cyanobacteria (Kennard and James, 1986) and the 
61 colonization of microbial surfaces by seaweeds (Feldmann and McKenzie, 1998) to the

62 disruption of originally laminated structures by bioturbation or diagenesis (e.g. Chafetz,

63 1973; Hofmann, 1973; Walter and Heys, 1985; Tarhan et al., 2013; Bernhard et al.,

64 2013).

65 Viewed broadly, the carbonate record suggests that metazoans and microbial mat

66 communities are antagonistic, with mat colonization reduced through time by metazoan

67 grazing and competition for space on the shallow seafloor (e.g., Awramik, 1971; Garrett,

68 1970). Yet, the co-occurrence of microbialites and carbonate skeletons through some fifty

69 million years of early Paleozoic history suggests a richer array of ecological interactions.

70 In western Newfoundland, a well-preserved Cambrian to Lower Ordovician carbonate

71 succession contains both microbialites and animal fossils, providing an opportunity to

72 evaluate the spatial relationships between animals and microbial communities during the

73 time when both populated coastal oceans. In this succession, we demonstrate that while

74 animal trace fossils and microbialites only rarely have overlapping facies distributions,

75 supporting the hypothesis of antagonism, skeletons of benthic invertebrates commonly

76 co-vary positively with thrombolites, indicating biological facilitation between microbial

77 bioherms and at least some animals.

78

79 2. Geologic setting

80

81 The Cambro-Ordovician Port au Port and St. George groups of western

82 Newfoundland crop out in the study area (Fig. 1) in several well-exposed sea-cliffs along

83 the south-facing shore of the Port au Port Peninsula. The stratigraphy is exposed across

84 two arms of a broad gently-dipping anticline, the axis of which runs through Marches 
85 Point (James and Stevens, 1982; Levesque, 1977). Depositional ages are constrained

86 primarily by means of biostratigraphy, particularly trilobite zones (Westrop, 1992);

87 identification of the SPICE carbon isotope excursion corroborates biostratigraphic

88 placement (Saltzman et al., 2004; Hurtgen et al., 2009). The uppermost Cambrian Series

893 and Furongian (traditionally, upper Middle and Upper Cambrian) Port au Port Group

90 consists from stratigraphically lowest to highest of the March Point, Petit Jardin and

91 Berry Head formations, a mixed carbonate-siliciclastic succession deposited in shallow

92 subtidal to peritidal settings. Carbonates include abundant oolite, thin-bedded limestone

93 with desiccation or diastasis cracks (Cowan and James, 1992), microbial limestone and

94 dolostone, and lenses of flat-pebble conglomerate, with lesser amounts of shale and

95 siltstone. The overlying St. George Group, deposited during Early Ordovician time,

96 consists, from lowest to highest, of the Watts Bight, Boat Harbour, Catoche, and

97 Aguathuna formations (e.g., Knight and James, 1987). These units are predominantly

98 carbonate, and facies record deposition in peritidal to shallow subtidal settings. As in the

99 underlying units, microbial build-ups are common (Knight and James, 1987; Pratt, 1980).

100 Carbonate facies include fine-grained bioturbated limestone, mudcracked, thinly-bedded

101 limestone and microbial laminite. Some reef complexes are large in comparison to

102 Cambrian build ups, particularly the sponge-microbial reef at Green Head in the Watts

103 Bight Formation (Pratt, 1980; Pratt and James, 1982). The Green Head reef represents the

104 lowermost microbial-metazoan complex preserved in these Cambro-Ordovician strata;

105 despite the presence of sponges, however, reef fabrics are still predominantly microbial.

106 The Boat Harbour Formation, exposed near Isthmus Bay, overlies the Watts Bight

107 Formation (Knight and James, 1987), the formational contact characterized by an

108 erosional surface (Knight et al., 2008). Boat Harbour rocks record deposition in shallow 
109 subtidal to supratidal environments, with evidence of episodic exposure. Carbonate

110 lithologies include micrite, calcareous siltstone, microbialite, oolite, and rare skeletal

111 grainstone. We begin by describing a $\sim 12 \mathrm{~m}$ succession of exceptionally preserved

112 stacked parasequences about 40 meters above the the base of the Boat Harbour

113 Formation. We focus inititally on this unit because its abundant stromatolites,

114 thrombolites, and metazoan traces and skeletons provide a framework for exploring

115 relationships between microbialites and animals that can then be exported to consider

116 coeval carbonates more generally.

117 To complement petrographic data on three Boat Harbour microbialites, we

118 quantified the composition of 22 additional thrombolites and stromatolites from the

119 Furongian Cape Ann and Campbell's members of the Port au Port Formation, as well as

120 the Jangle Member of the Series 3 (middle) Cambrian Carrara Formation exposed near

121 Death Valley, California (Table 1; Adams and Grotzinger, 1996). Examination of thin

122 sections in at least one area outside of Newfoundland permits some exploration of how

123 generalizable our observations from the Port au Port and St. George groups are. Each thin

124 section was point counted (sensu Flügel, 2004, Pruss and Clemente, 2011) and compared

125 to the Boat Harbour microbialites.

126

127 3. Boat Harbour parasequences

129 A series of thickening-upward parasequences in the Lower Ordovician Boat

130 Harbour Formation (Fig. 2) record repeated flooding and exposure in a clear water

131 coastal setting. Parasequence boundaries are marked by flooding surfaces, lag deposits 
132 and, in some cases, erosion (see Fig. 2). This thickening stack of parasequences indicates

133 deepening during deposition, with the deepest facies near the top of the succession.

134 Individual parasequences show some general trends. Laminated calcilutite

135 commonly characterizes flooding surfaces and is commonly the initial surface on which

136 microbial mounds develop. Within the basal $4 \mathrm{~m}$ of this section, each microbial unit

137 consists of domal stromatolites overlain by blunt stromatolitic columns that more or less

138 retain the overall domical shape of the build-ups (Fig. 2, PAR 1-2). Mounds are about 10

$139 \mathrm{~cm}$ thick, with a synoptoic relief of no more than a few $\mathrm{cm}$. Microbial units begin to

140 increase in thickness above the 4 meter mark, even though fabrics remain similar (PAR

$1413-5)$. In these lower parsequences, stromatolitic mounds are commonly overlain by fine-

142 grained limestones that preserve desiccation cracks. The columnar stromatolites in the

143 upper part of build-ups are commonly brecciated, complementing dessication cracks in

144 documenting upward shallowing to exposure at the tops of parasequences.

145 Parasequences that conform to this general pattern continue to thicken upward; at

$1465.75 \mathrm{~m}$ above the base of the succession, there is a pronounced increase in both the

147 abundance and dimensions of domal stromatolites (PAR 6). In this parasequence,

148 microbial domes are continuous through about $.7 \mathrm{~m}$ of strata; although synoptic relief was

149 likely not more than $10 \mathrm{~cm}$. Intraclasts occur in the troughs between domes, and the

150 upper $10 \mathrm{~cm}$ of the build ups exhibit a pseudocolumnar morphology. The largest

151 stromatolitic mounds occur at $\sim 7.0 \mathrm{~m}$, where a discontinuous series of $3-\mathrm{m}$ wide mounds

152 can be seen (PAR 8). This is also the horizon where thrombolites first occur as

153 conspicuous components of the succession.

154 Within parasequence PAR 8, an increase in accomodation space is recorded in the 155 large (meter-thick) microbial structures with synoptic relief of perhaps half a meter. In 
156 the overlying parasequence (PAR 9), a 0.45-m thick oolitic horizon hosts large domal

157 stromatolites; ooids surround, overlap, and occur within the laminae of the microbialites.

158 Meter-scale thrombolite mounds cap the oolitic stromatolites. This horizion also contains

159 the first significant contribution of bioclastic material, in beds that flank the thrombolites

160 as well as within the thrombolite mounds themselves. Thrombolites, in turn, are overlain

161 by $\sim 0.5 \mathrm{~m}$ of intraclastic skeletal grainstone and then $2.5 \mathrm{~m}$ of moderately bioturbated

162 calcisiltite (ichnofabric index of 3; Droser and Bottjer, 1986). No microbialites occur in

163 these uppermost part of the succession.

164

165 4. Environmental distributions of microbialites and metazoans

166

167 As introduced above, small-scale sea-level changes are reflected in approximately

$168 \sim 12 \mathrm{~m}$ of shallow water carbonates that preserve abundant microbialites and sedimentary

169 structures in the Boat Harbour Formation (Figs. 3-5). The preservation of microbial build

170 ups within this series of well-exposed thickening upwards parasequences provides an

171 opportunity to track how subtle changes in environment influenced microbialite form.

172 Parasequences initially show an overall thickening, suggesting these are preserved as part

173 of a larger transgressive sequence (Knight et al., 2008), represented in outcrop as a

174 change in carbonates from abundant microbialites that exhibit evidence for exposure to

175 skeletal packstones and grainstones and bioturbated limestones. The maximum depth

176 reflected in these parasequences is likely represented by the large thrombolitic units

177 flanked by skeletal limestones (Knight et al., 2008), which suggest local sediment

178 starvation during sea-level rise. 
181 Peritidal facies: low relief domal, columnar, and pseudocolumnar stromatolites (Fig. 3A,

182 B) capped by desiccation cracks (Fig. 3C) and exposure surfaces are best developed in

183 the lower parasequences (PAR 1-7 of Fig. 2). In this setting, low domal stromatolites are

184 often the first microbial structures to accrete on calcilutite surfaces. Laminations are

185 visible in hand sample, but are not always apparent in thin-section (Fig. 6); petrographic

186 fabrics include peloids and renalcid-like mesoclots Fig. 6B, C). In a few instances, wavy

187 laminations pinch and swell laterally, suggesting microbial trapping and binding.

188 Columnar and pseudcolumnar stromatolites (Fig. 3B, D) commonly occur at the tops of

189 microbial mounds. Columns are internally brecciated, and the synoptic relief of

190 individual columns is typically less than $10 \mathrm{~cm}$. Columnar structure is occasionally

191 complex, with a lower interval of irregular brecciated pseudocolumns capped by discrete,

192 laterally linked columns. In thin section, columns exhibit a coarsely laminated peloidal

193 fabric (Fig. 6B). In general, the spaces between columns are filled by coarse sediment,

194 including intraclasts sourced from nearby mounds.

195 The microbialites are overlain by calcisiltites to lutites, with some terrigenous

196 material and thin intraclast beds, likely representing flooding during deposition of

197 overyling parasequences. The tops of parasequences often contain exposure surfaces

198 marked by discontinuous silicification (Fig. 3F). Animal fossils are uncommon, but

199 gastropods and trilobite debris occasinally occur in troughs between mounds.

200

201 4.2. More persistently flooded platform environments

202 The largest domal stromatolites in our succession occur in PAR 8-9, where they 203 are capped by equally thick thrombolites (Fig 4A). Here, the domes reach nearly half a 
204 meter in thickness, commonly with columns developing near their tops. The stromatolites

205 are associated with ooid sands (Figs. 3E), with ooids commonly preserved within chert

206 nodules in the troughs between columns. The thrombolite fabric directly overlies

207 individual stromatolitic columns, suggesting essentially continuous deposition of this

208 bioherm. In thin-section, oolitic stromatolites at the base of the complex exhibit a diffuse

209 peloidal fabric with abundant recrystallized ooids preserved in some laminae. The ooids

210 are occasionally truncated from partial dissolution (Fig. 6E); small intraclasts are also

211 preserved between stromatolite columns.

212 Discrete $55 \mathrm{~cm}$ thick thrombolite mounds formed on top of the oolitic stromatolite

213 horizon (Fig. 4). The thrombolites are $1 \mathrm{~m}$ wide and laterally continuous. In outcrop, their

214 macrofabric consists of renalcid-like, sparry carbonate surrounded by skeletal material

215 (Fig. 4C). Gastropods and disaggregated fossil material are preserved in the interstices of

216 mesoclots (Fig. 6D, E). The skeletal material is coarse and is also preserved in beds that

217 lap out against the sides of the mounds. Synoptic relief was likely about $20-50 \mathrm{~cm}$. The

218 thrombolitic fabric occurs in interstitial clasts but is generally overlain by coarse skeletal

219 debris. The thrombolites themselves are draped by $\sim 0.5 \mathrm{~m}$ of intraclastic skeletal

220 grainstone. In thin section, thrombolite mounds contain a diffuse microbial fabric that

221 also appears peloidal (Fig. 6D, E). Gastropods, trilobites, echinoderms, nautiloids and

222 other fossil debris are visible in outcrop (Fig. 5A, B) and also occur within thin sections

223 of the thrombolite mound. Samples taken from between mounds also contain fossil

224 material, as do thrombolitic intraclasts. Skeletal material is most abundant within the

225 thrombolite mounds and in beds flanking them (Fig 5A, B).

226 The uppermost portion of our Boat Harbour succession does not contain

227 microbialites, but preserves abundant evidence of animal life. Cm-scale burrows occur 
228 throughout the silty to fine sandy carbonates (Fig. 5C, D), and skeletons of gastropods,

229 brachiopods, and trilobites are widely distributed (see Fig. 5A).

230

231 5. Controls on Boat Harbour microbialite distribution

232

233 In the Boat Harbour succession, then, we see a clear partitoning of microbialites

234 among facies developed within and among parasequences. Stromatolites occur in

235 restricted coastal facies marked by a low influx of mud and coarser clastic carbonates.

236 Thrombolites occur in shallow subtidal facies where traction load sediments are sparse.

237 And microbialites are absent off-shore, where bioturbated, fine-grained clastic carbonates

238 predominate.

239 Parasequences generally shallow upward (Van Waggoner et al., 1988; 1990), and

240 in Early Paleozoic microbialite-dominated successsions, stromatolites tend to cap

241 thrombolites (e.g., Kennard and James, 1986; Armella, 1994; Montanez and Osleger,

242 1993), although this is not always the case. Much of what we observe in the Boat

243 Harbour succession is consistent with the expectations of upward shallowing. In

244 parasequence PAR 9, however, thrombolites conspicuously cap stromatolites. Deepening

245 upward parasequences have been recorded in Cambro-Ordovician carbonates (e.g.,

246 Kennard and James, 1986; Lukasik and James, 2003; Myrow et al., 2012); however, we

247 suspect that another factor governs this pattern locally. On modern carbonate platforms,

248 thrombolitic fabrics commonly develop where seaweeds (or animals) grow on

249 microbialite surfaces; stromatolites persist where colonization by fleshy algae or animals

250 is inhibited (Feldmann and Mackenzie, 1998; Andres and Reid, 2006). Inhibition of

251 colonizing benthos can reflect elevated salinity or frequent exposure -- in general, the 
252 reasons why Cambro-Ordovician stromatolites most commonly accreted in restricted

253 environments. Algal or animal colonization, however, can also be inhibited by physical

254 factors, including constant scouring by ooids (for example, among the Exuma Cays in the

255 Bahamas; Mcintyre et al., 1996; Andres and Reid, 2006; Andres et al., 2009). Consistent

256 with this hypothesis, the large subtidal stromatolites in PAR 9 developed in close

257 association with ooids, and when ooid influx stopped, microbialite fabrics switched from

258 lamination to thombolitic clots.

259 How are animals distributed along the same Boat Harbour gradient and how, in

260 turn, does this reflect ecological relationships among microbial benthos, animals and

261 macroalgae in Cambro-Ordovician seaways? Stromatolites accreted commonly in

262 restricted environments along the margins of Proterozoic oceans and contiued to do so

263 through much of the Phanerozoic Eon. This pattern is consistent with antagonistic

264 arguments about microbial mats and animals (Kepper, 1974): when and where animals

265 were absent because of evolution (Proterozoic) or either physical or chemical

266 environmental restriction (Phanerozoic), stromatolites accreted. In the Boat Harbour and

267 other coeval successions, however, the reverse does not hold: the presence of animals

268 does not neatly coincide with an absence of microbialites. In subtidal sands and muds,

269 motile benthos is widely recorded by tracks and trails, and less so by skeletons. Such

270 animals might have inhibited microbial mat development by disrupting sediments and

271 grazing; however, a lack of firm substrates would also have imposed restrictions on mat

272 development, as could persistent traction load movement. Consistent with this, in shallow

273 environments where traction load was low, stromatolites per se did not form, but

274 thombolites accreted widely. Sessile benthic animals, echinoderms locally, but sponges

275 elsewhere (e.g., Pratt and James, 1982; Shapiro and Awramik, 2002; Lee et al., 2015; 
276 Coulsen and Brand, 2016), colonized the hard substrates provided by accreting

277 thrombolites. This bespeaks a more positive ecological relationship between mats and

278 benthos - one of biological facilitation.

279 All thin sections, including those from the Cambrian and Ordovician of western

280 Newfoundland and the Carrara Formation in the Death Valley region, preserve a general

281 trend: stromatolites are more or less devoid of skeletal debris, with skeletons comprising

282 only 4 points of the 2000 counted from stromatolitic thin sections (Fig. 7, Table 1). In

283 contrast, thrombolites contain as much as $9 \%$ skeletal material in thin section.

284 Furthermore, skeletons are present in 13 of the 15 thrombolitic thin sections examined.

285 This suggests that skeletons are generally present in thrombolites but are only rarely

286 preserved in stromatolites, corroborating outcrop level observations of Boat Harbour 287 microbialites.

288 We believe that it is also important to consider a role for macroalgae in 289 thrombolite fabric generation and invertebrate distribution. Seaweeds are not preserved

290 within Boat Harbour carbonates, and so any discussion of their impact involves

291 speculation. Nonetheless, there are at least three reasons for exploring the potential

292 ecological and sedimentary importance of macroalgae along Cambro-Ordovician

293 seacoasts. First, nektonic macroalgae are known to have existed on Cambrian and Early

294 Ordovician seafloors (LoDuca et al., 2017). Second, a host of observations and

295 experiments, some outlined below, document the roles played by macroalgae in the

296 generation of thrombolitic fabrics and the distribution of reefs in modern marine

297 environments. And third, sedimentary patterns that are recorded in the Boat Harbour

298 succession are consistent with observations of macroalgae and their grazers in modern

299 ecosystems. Thus, we believe that we ignore this fuller ecosystem framework at our peril. 
On the modern Bahamian platform, clotted thrombolitic fabrics are associated

301 with subtidal microbialites festooned with fleshy algae; algal holdfasts govern the

302 observed discontinuous cementation pattern (Feldmann and McKenzie, 1998).

303 Consistent with this, both sessile benthic animals (Erwin et al., 2011) and macroalgae

304 (LoDuca et al., 2017) radiated within the same time frame that thrombolites expanded

305 across shallow platforms. Thrombolite expansion also correlates in time with the

306 expansion of animal bioturbation, but evidence for the disruption of hard substrates by

307 burrowing metazoans is limited in Cambrian and Lower Ordovician carbonates (Buatois

308 et al., 2016), and petrographic observations favor $\mathrm{mm}$ - to $\mathrm{cm}$-scale spatial variations in

309 precipitation as the source of thrombolitic fabric (Kennard and James, 1986). Theisen and

310 Sumner (2016) noted the association of bioturbation with clotted diagenetic fabrics in

311 Cambrian thrombolites from the Great Basin, but emphasized that the disrupted fabrics

312 were themselves thrombolitic and not laminated. In general, bioturbation and other

313 bioerosional processes can alter primary microbialite fabrics, but are not the source of

314 them (Bernhard et al., 2013). And, importantly, the role of ooid sands in delimiting

315 stromatolites vs. thrombolites cannot easily be ascribed to changes in seawater saturation

316 with respect to carbonate minerals, but makes good sense in light of the colonization

317 hypothesis. Thus, colonizing fleshy algae and invertebrates may explain both the

318 thrombolite fabrics as well as their spatial association with sessile benthos such as stalked

319 echinoderms.

320 While sessile invertebrates were present on thrombolitic surfaces, biomass was

321 commonly low (Pruss et al., 2010; Creveling et al., 2013; Table 1). Macroalgae might

322 have played a role here, too, by competing successfully for space on the firm thrombolite

323 surface, thereby limiting colonization by sessile invertebrates. In ecological experiments 
324 where boxes were placed over coral reefs to exclude macroalgal grazers, fleshy algae

325 commonly expanded dramatically, sharply reducing benthic invertebrate populations

326 (e.g., Lewis, 1986; Vermeij et al., 2010). Grazer evolution, then, might well have

327 influenced the distribution of skeletal animal benthos among thrombolites. [It is possible

328 that macroalgal grazers existed among Cambrian mollusks, but the major groups of

329 gastropods, echinoderms, vertebrates and arthropods that dominate macroalgal herbivory

330 in modern oceans began to diversify only during the Ordovician radiation or later (Iken,

331 2012; Zapata et al., 2014).]

332 At the same time, macroalgae would have provided a local source of nutrition for

333 primary and secondary consumers, helping to explain the facies association between

334 thrombolites and motile animals such as trilobites and nautiloids (Pratt and James, 1982).

335 Elser et al. (2006) have argued that microbial mats provide a poor source of nutrition for

336 metazoan grazers, and studies of modern environments where microbialites and animals

337 co-occur demonstrate that grazing metazoans strongly favor macroalgae as a food source,

338 feeding little if at all on microbial mat populations (Risworth et al., 2017).

339

340 6. Stromatolites and thrombolites in space and time

Microbial build ups broadly comparable to those of the Boat Harbour succession

344 are conspicuous features of the Port au Port and St. George groups (Chow, 1985;

345 Kennard, 1988; Kennard and James, 1986). Though common, microbial build ups are

346 rarely $>1 \mathrm{~m}$ in thickness, and many of the forms did not attain significant topographic

347 relief above the seafloor. 
The first conspicuous microbial build ups in Lower Ordovician strata on the Port

349 au Port Peninsula are preserved in the Watts Bight Formation (Figs. 2, 8A), which

350 underlies the Boat Harbour Formation. Approximately 25 meters above the base of the

351 Watts Bight Formation, the Green Head complex is exposed (Pratt, 1980; Pratt and

352 James, 1982). This reef consists of large coalescing thrombolitic mounds that are flanked

353 by grainstones and preserve a complex architecture (Fig. 8A). The relationship between

354 flanking beds and the thrombolite mounds suggests the reef may have attained meters of

355 relief above the seafloor. Large cephalopod and gastropod fossils are preserved in the

356 interstices of microbial mounds, and sponges possibly added to the framework of the reef

357 (Pratt and James, 1982). This Lower Ordovician complex is laterally extensive (>10

358 meters) and contains relatively abundant fossil material.

359 In units overlying the Green Head complex, a 3 m-thick limestone unit contains

360 alternating beds of thrombolite and grainstone (Fig. 8B). The largely dolomitized

361 thrombolite bioherm is similar in form to Favosamaceria cooperi (Shapiro and Awramik,

362 2006), consisting of upward-oriented, occasionally anastomosing thrombolitic columns

363 with abundant trace fossils in fine-grained limestone deposited between the columns (see

364 Fig. 8B). Thrombolites are overlain by skeletal grainstones that contain abundant large

365 cephalopods, and a $\sim 0.5 \mathrm{~m}$ thrombolite-stromatolite bed caps this unit. Small stromatolite

366 domes ( $5 \mathrm{~cm}$ in diameter) are exposed at the top of the section.

367 Much like the Boat Harbour microbial units, skeletal material is a common

368 constituent of thrombolitic mounds in the Green Head Complex, and stromatolitic fabrics

369 tend to dominate in areas of higher traction load sedimentation. Gastropods, cephalopods

370 and sponges lived on or near these microbial mounds as they accreted, and some

371 probably influenced their development. Given an increase in accommodation space, large 
372 bioherm complexes could develop. The abundance of skeletal material in these and other

373 thrombolitic units also suggests that the presence of grazers such as gastropods did not

374 interfere with microbial reef development.

375 In underlying Cambrian units, microbial mounds are also common (see Fig. 2),

376 and these build ups again reflect environmental influences similar to those that shaped the

377 Boat Harbour microbialites. For instance, the Furongian Cambrian Cape Ann and

378 Campbell's members contain abundant microbial build ups that show evidence for in situ

379 precipitation of carbonate (Fig. $8 \mathrm{C}-\mathrm{E}$ ); a few representative samples were examined in

380 hand sample and point counted for comparison with the Boat Harbour microbialites. The

381 Cape Ann and Campbell's thrombolites often preserve renalcid-like fabrics in slab view

382 and in thin section, and nearly all of them preserve skeletons (Fig. 6F). Thrombolitic

383 cores commonly have stromatolitic caps (Kennard and James, 1986; Kennard, 1988),

384 likely representing small-scale shallowing-upward events in subtidal settings. The

385 thrombolitic bases formed in deeper-water settings during sediment starvation, and the

386 stromatolitic columns followed as traction load influx increased. In thin section, trilobites

387 and echinoderms are the most common fossil constituents (Table 1, Fig. 6F), with much

388 rarer contributions from brachiopods and molluscs.

389 In thrombolites and stromatolites of the Carrara Formation, California, a similar

390 pattern emerges. These structures are most common in the carbonate-dominated Jangle

391 Limestone Member of the Carrara Formation, and it should be noted that although

392 oncoid-rich beds are also common in this unit (Adams and Grotzinger, 1996), they were

393 excluded from this analysis. Fossils are rare in hand samples and thin sections of the

394 Carrara stromatolites. In contrast, skeletons make up as much as $16 \%$ of points counted

395 from the thrombolites, and they are present in all but one thin section. Renalcid fabric, 
396 though visible in hand sample, is often not well preserve in thrombolite thin sections.

397 Again, trilobites and echinoderms make up the vast majority of the skeletal material in

398 thrombolites (Table 1). On the whole, stromatolites are less common in this unit than

399 thrombolites; nonetheless, skeletal material is most abundant in Carrara thrombolites

400 (Fig. 7), similar to the microbialites of Newfoundland. Indeed, such spatial relationships

401 among microbialites and metazoans occur widely in Cambro-Ordovician platform

402 carbonates observed globally (e.g., Lee et al., 2015).

403

404 6.2. Stromatolites and thrombolites in time

405 In Proterozoic oceans, stromatolites accreted from restricted coastal lagoons to the

406 base of the photic zone (Grotzinger and Knoll, 1999). Stromatolite abundance appears to

407 have decreased somewhat in Neoproterozoic oceans, perhaps in conjunction with the

408 expansion of eukaryotic benthos (Monty, 1973; Knoll and Swett, 1990; Grotzinger and

409 Knoll, 1999; Peters et al., 2017), but stromatolites remained principal features of

410 carbonate stratigraphy until the end of the eon. Beginning in the Cambrian Period,

411 stromatolites were increasingly confined to restricted coastal environments and subtidal

412 settings characterized by shifting sands, as observed in the Boat Harbour succession.

413 Thrombolites, however, emerged as important features of subtidal carbonates where

414 traction load was limited (e.g., Riding, 2000; Rowland and Shapiro, 2002; Shapiro and

415 Awramik, 2006; Bernhard et al., 2013; Lee et al., 2015). This stratigraphic pattern has

416 been attributed to, among other things, the Paleozoic expansion of metazoans that grazed

417 on microbialites or competed with them for space on the shallow seafloor; the radiation

418 of macroalgae, which colonized microbialite surfaces, governing textural signatures;

419 changing availability of hard grounds; and changing carbonate oversaturation in coastal 
420 oceans. Thrombolites subsequently declined in distribution during the later Ordovician,

421 as heavily skeletonized sessile benthic invertebrates radiated across shelves and platforms

422 (Harper, 2006).

423 The facies distributions of animals and microbialites in the Boat Harbour

424 succession and elsewhere indicate that ecological relationships between Cambro-

425 Orodivican animals and microbial mat populations were diverse. As the Cambrian

426 dawned, stromatolites became progressivley restricted to environments where animals

427 could not gain an ecological foothold, supporting the view that animal radiation

428 influenced the spatial distribution of microbial mats. To a significant extent, however,

429 subtidal stromatolites were supplanted not by animal reefs or shell beds, but by

430 thrombolitic microbialites. Thus, microbial mats continued to colonize broad areas of the

431 subtidal photic zone where traction load sedimentation was low, and these mats

432 continued to mineralize and build relief. Moreover, these build-ups actually facilitated

433 populations of sessile benthic invertebrates and macroalgae that depend on firm

434 substrates.

435 Hardgrounds are generally uncommon in Cambrian carbonate successions (Taylor 436 and Wilson, 2003); thus, sessile benthos that require firm substrates may have thrived on

437 subtidal thrombolitic surfaces. (In principle, stromatolite surfaces would also have

438 provided hard substrates for colonization; however, the dearth of evidence for

439 macrobenthos in these structures suggests that other factors - for example exposure or

440 salinity - restricted their abundance.) In addition to colonizing thrombolites, sessile

441 Cambrian benthos requiring firm substrates grew epifaunally on animals and on their

442 skeletal remains (Vinn, 2017); even in muddy environments like the Burgess Shale, 443 articulate brachiopods found firm anchorage on other organisms and shells (Topper et al., 
444 2017). Today, macroalgae occur abundantly in reef settings on hard substrates,

445 particularly where grazers are limited (e.g., Lewis, 1986; Vermeij et al., 2010). Since

446 these algae were radiating in Cambrian and Ordovician oceans, it is likely that they, too,

447 colonized thrombolitic mounds, particularly before macroalgal grazers had attained their

448 current ecological importance (Seilacher, 1999). Macroalgal growth, then, may have

449 played a role in thrombolite fabric development, while providing nutrition for motile

450 animals whose fossils indicate a preference for thrombolite environments. We note as

451 well that meiofuana are common consitutents of modern microbialites (Glud et al., 1995;

452 Tarhan et al., 2013), although their role if any in thrombolitic fabric generation remains

453 to be documented; small invertebrates also occur within microbial mats in restricted

454 lagoonal and microbial marsh environments (e.g., Gomes et al., 2016).

455 Thrombolite abundances, morphologies, and fabrics vary in time and space within

456 their Cambro-Ordovician acme, reflecting animal (the demise of archaeocyaths and

457 expansion of other sponges) and algae (diversification of dascyclads) as well as changes

458 in local physical and chemical environments (Rowland and Shapiro, 2002; Lee et al.,

459 2015; Zhang et al., 2016; Theisen and Sumner 2016). Nonetheless, we believe that the

460 interactions among physical environment, microbial communities, radiating animals, and

461 macroalgae argued to govern relationships observed in Cambro-Ordovician strata of

462 western Newfoundland have a more general application.

463 What factors, then, might have contributed to the later Ordovician decline in

464 thrombolite abundance? A full discussion of biological and physical changes

465 underpinning Ordovician animal radiation (Algeo et al., 2016), is beyond the scope of

466 this paper, but a few comments are in order. First, a significant increase in hardground

467 distribution (Taylor and Wilson, 2003), perhaps in tandem with expanded grazing 
468 pressure on macroalgae by an increasingly diverse and abundant marine fauna, may well

469 have tipped the scales in favor of sessile benthic metazoan colonization of the shallow

470 seafloor. Wright and Cherns (2016) attribute hardground expansion to an Ordovician

471 increase in bioturbation depth - another, albeit indirect, ecosystem influence of animals,

472 further restricting microbial communities while facilitating the radiation of heavily

473 skeletonized, sessile invertebrates that require such hard substrates. We note, as well, that

474 the Ordovician radiation, an event defined by an expansion of marine macrobenthos, also

475 included a major increase in skeletonized macroalgae (Wray, 1977), supporting the idea

476 of increased grazer pressure.

477 Microbially influenced sedimentary structures continued to form in siliciclastic

478 environments, indicating that microbial mats were not banished completely from younger

479 coastal environments; existing data, however, do not permit estimates of commonness for

480 such features (Davies et al., 2016). Microbialites require both mat formation and

481 mineralization. Riding $(2000,2005)$ proposed that Phanerozoic microbialite abundance

482 reflects changing levels of seawater oversaturation with respect to calcite and aragonite, a

483 view supported by Peters et al. (2017). Declining carbonate oversaturation could, in

484 principle, have impeded microbialite mineralization, providing a physical influence on

485 thrombolite decline. Estimating the saturation level of ancient oceans, however, is

486 challenging, as illustrated by a comparison of Riding and Liang (2005) with Arvidson et

487 al. (2013): Riding and Liang (2005) proposed that $\Omega$ was extremely high in early

488 Paleozoic oceans and then declined through the remainder of the era; in contrast,

489 Arvidson et al. (2013), who took changing pH into account, concluded that $\Omega$ increased

490 through the era. Importantly, neither analysis indicated a major change in carbonate

491 saturation levels during the Cambrian and Ordovician interval in question. Nonetheless, 
492 to the extent that $\mathrm{pCO}_{2}$ declined from the Cambrian through the Orodivician (Berner and

493 Kothavala, 2011), increasing pH (Halevy and Bachan, 2017) and decreasing temperature

494 (Trotter et al., 2008) would have increased supersaturation with respect to carbonate

495 minerals. According to the Neritan ocean hypothesis (Zeebe and Westbroek, 2003),

$496 \mathrm{CaCO}_{3}$ biomineralization by animals could have kept surface water saturation levels

497 below the theshhold required for abiotic carbonate precipitation, so the Ordovician

498 expansion of carbonate skeletons could have had at least a small influence on surface

499 water $\Omega$. In any event, however, microbialite mineralization depends critically on the

500 saturation levels of pore waters within mats, a parameter under strong control by

501 heterotrophic metabolism (Dupraz et al., 2009). Thus, changes in seawater chemistry,

502 either physically or biologically induced, probably played at best a subordinate role in the

503 Ordovician decline of thrombolites. Animal competitors for space, grazers, and

504 bioturbators are the most likely candidiates for microbialite decline.

505

506 7. Conclusions

507

508 The microbal build-ups preserved in an upward thickening succession of

509 parasequences within the Lower Ordovician Boat Harbour Formation, western

510 Newfoundland, provide insights into the development and distribution of distinct types of

511 microbialites and animals. Microbialite distributions reflect interactions between Early

512 Paleozoic environments and ecology. Many of the microbialites described here exhibit

513 fabrics consistent with in situ microbially-mediated precipitation of carbonate.

514 Stromatolites in these sections are typically devoid of fossils whereas thrombolites

515 contain relatively abundant skeletal material, reflecting both hard substrates for sessile 
516 organisms such as eocrinoids and local sources of food provided by macrolgae that also

517 colonized thrombolitic surfaces. Cambro-Ordovician animals do not display a uniform

518 relationship to microbialites because animals are not structurally, functionally or

519 ecologically monolithic. In Cambrian and Early Ordovician oceans, motile benthic

520 organisms contributed to the environmental restriction of microbial communities, but

521 thrombolites facilitated sessile benthos and nekton. With the expansion of hardgrounds,

522 the increased depth and environmental amplitude of bioturbation, and the concomitant

523 diversification of biomineralized sessile benthic animals, microbial build ups largely

524 disappeared from open marine environments.

525

526 Acknowledgments

527 AHK thanks the NASA Astrobiology Institute for support of this research. SBP

528 acknowledges the Agouron Institute for the initial funding for this project, Smith College

529 for subsequent support, and T. McGann for thin section analyses.

\section{References}

533 Adams, R. D. and Grotzinger, J. P. 1996. Lateral continuity of facies and parasequences

534 in Middle Cambrian platform carbonates, Carrara Formation, southeastern

535 California, USA. Journal of Sedimentary Research, 66:1079-1090

536 Aitken, J. D. 1967. Classification and environmental significance of cryptalgal limestones

537 and dolomites, with illustrations from the Cambrian and Ordovician of

538 southwestern Alberta. Journal of Sedimentary Research, 37: 1163-1178. 
539 Aitken, J.D. and Narbonne, G.M. 1989. Two cccurrences of Precambrian thrombolites

540 from the Mackenzie Mountains, Northwestern Canada. Palaios 4: 384-388.

541 Algeo, T.J., Marenco, P.J. and Saltzman, M.R. 2016. Co-evolution of oceans, climate,

542 and the biosphere during the 'Ordovician Revolution': A review.

543 Palaeogoeogrpahy, Palaeoclimatology, Palaeoecology, 458: 1-11.

544 Armella, C. 1994. Thrombolitic-stromatolitic cycles of the Cambro-Ordovician boundary

545 sequence, Precordillera Oriental Basin, western Argentina. In: Phanerozoic

546 stromatolites II, (Eds J. Bertran-Sarfati and C. Monty), Kluwer, Netherlands: 421-

$547 \quad 441$.

548 Arvidson, R.S., Mackenzie, F.T and Guidry, M.W. 2013. Geologic history of seawater: A

549 MAGic approach to carbon chemistry and ocean ventilation. Chemical Geology, $550 \quad 362: 287-304$.

551 Andres, M. S. and Reid, R. P. 2006 Growth morphologies of modern marine

552 stromatolites: A case study from Highborne Cay, Bahamas. Sedimentary Geology,

$553 \quad 185: 319-328$.

554 Andres, M.S., Reid, R.P. and Bowlin, A.E. 2009. Microbes versus metazoans as

555 dominant reef builders: insights from modern marine environments in the Exuma

556 Cays, Bahamas. International Association of Sedimentologists Special

557 Publication, 41: 149-165

558 Awramik, S.M. 1971. Precambrian columnar stromatolite diversity; Reflection of

559 metazoan appearance. Science, 174: 825-827.

560 Awramik, S.M. 1992. The history and significance of stromatolites. In: Early Organic

561 Evolution, (Eds M. Schidlowski, S. Golubic, M. M. Kimberly, D. M. McKirdy, 562 and P. A., Trudinger), Springer, Berlin, pp 435-449. 
563 Berner, R.A. and Kothavala, Z. 2001. GEOCARB III: a revised model of atmospheric

$564 \quad \mathrm{CO}_{2}$ over Phanerozoic time. American Journal of Science, 301: 182-204

565 Bernhard, J. M., Edgcomb, V. P. Visscher, P. T. McIntyre-Wressniga, A. Summons, R.

566 E., Bouxseind, M. L. Louis, L. and Jeglinskia, M. 2013. Insights into

567 foraminiferal influences on microfabrics of microbialites at Highborne Cay,

568 Bahamas, Proceedings of the National Academy of Sciences, USA 24: 9830-4.

569 Buatois, L. A. Mángano, M. G. Olea, R. A. Wilson, M. A. 2016. Decoupled evolution of

570 soft and hard substrate communities during the Cambrian Explosion and Great

571 Ordovician Biodiversification Event, Proceedings of the National Academy of

$572 \quad$ Sciences, USA, 113, 6945-6948.

573 Chafetz, H.S. 1973. Morphological evolution of Cambrian algal mounds in repsonse to a

574 change in depositional environment. Journal of Sedimentary Petrology, 43: 435-

$575 \quad 446$.

576 Chow, N. 1985. Sedimentology and diagensis of Middle and Upper Cambrian platform

577 carbonates and siliticlastics, Port au Port Peninsula, western Newfoundland.

$578 \quad \mathrm{PhD}$, Memorial University, St. John's, $458 \mathrm{pp}$.

579 Conliffe, J., Azmy, K., Knight, I., and Lavoie, D., 2009. Dolomitization of the Lower

580 Ordovician Watts Bight Formation of the St. George Group, western

$581 \quad$ Newfoundland: evidence of hydrothermal fluid alteration, Canadian Journal of

$582 \quad$ Earth Sciences, 46: 246-261.

583 Coulsen, K. P. and Brand, L. R. 2016. Lithistid sponge microbial reef-building

584 communities construct laminated, Upper Cambrian (Furongian) 'stromatolites'.

$585 \quad$ Palaios, 31: 358-370. 
586 Cowan, C.A. and James, N.P. 1992. Diastasis cracks: mechanicall generated synaeresis-

587 like cracks in Upper Cambrian shallow water oolite and ribbon carbonates.

$588 \quad$ Sedimentology, 39: 1101-1118.

589 Creveling, J. R. Fernández-Remolar, D. Rodríguez-Martínez, M. Menéndez, S.

590 Bergmann, K. D. Gill, B. C. Abelson, J. Amils, R. Ehlmann, B. L. García-Bellido,

591 D. C. Grotzinger, J. P. Hallman, C. Stack, K. M. and Knoll, A. H. 2013.

592

593

594

Geobiology of a lower Cambrian carbonate platform, Pedroche Formation, Ossa

Morena Zone, Spain. Palaeogeography, Palaeoclimatology, Palaeoecology, 386:

595 459-478.

Davies, N. S. Liu, A. G. Gibling, M. R. and Miller, R. F. 2016. Resolving MISS

596

597

conceptions and misconceptions: A geological approach to sedimentary surface textures generated by microbial and abiotic processes. Earth-Science Reviews, 154: $210-246$.

Dupraz, C. Reid, R. P. Braissant, O. Decho, A. W. Norman, R. S. and Visscher, P. T. 2009. Processes of carbonate precipitation in modern microbial mats, EarthScience Reviews, 96: 141-162.

Droser, M.L. and Bottjer, D.J. 1986. A semiquantitative field classification of ichnofabric. Journal of Sedimentary Petrology, 56: 558-559.

604 Elser, J.J. Elser, Watts,J., Schampel1, J.H. and Framer, J. 2006. Early Cambrian food 605 webs on a trophic knife-edge? A hypothesis and preliminary data from a modern stromatolite-based ecosystem. Ecology Letters, 9: 295-303

608

Erwin, D.H., Laflamme, M, Tweedt, S.M., Sperling, E.A., Pisani, D. and Peterson, K.J..

609 2011. The Cambrian conundrum: early divergence and later ecological success in the early history of animals. Science 334: 1091--1097. 
610 Feldmann, M. and McKenzie, J. 1998. Stromatolite thrombolite associations in a modern

611 environment, Lee Stocking Island, Bahamas. Palaios, 13:201-12.

612 Flügel, E. 2004. Microfacies of carbonate rocks: analysis, interpretation and application.

613 Springer, New York, 976 pp.

614 Garrett, P. 1970. Phanerozoic stromatolites: Noncompetitive ecologic restriction by

615 grazing and burrowing animals. Science, 169: 171-173.

616 Glud, R. N. Jensen, K. Revsbech, N. P. 1995. Diffusivity in surficial sediments and

617 benthic mats determined by use of a combined $\mathrm{N}_{2} \mathrm{O}-\mathrm{O}_{2}$ microsensor, Geochimica

$618 \quad$ et Cosmochimica Acta, 59: 231-237.

619 Gomes, M., Lingappa, U. Metcalfe, K. O'Reilly, S. S. Riedman, L. A. Cantine, M.

620 Ireland, B. Philips, R. Stein, N. Orzechowski, E. A. Strauss, J. V. Grotzinger, H.

621 M. Quinn, D. P. Trower, L. Fischer, W. W. Grotzinger, J. P. Knoll, A. H. and

622 Fike, D. A. 2016. Linking the modern to the ancient with a comprehensive

623 geobiological understanding of biosignature preservation in microbial mats.

624 American Geophysical Union, Fall Meeting: B21E-0467.

625 Grotzinger, J.P. and Knoll, A.H. 1999. Proterozoic stromatolites: evolutionary mileposts

$626 \quad$ or environmental dipsticks? Annual Review of Earth and Planetary Science, 27:

$627 \quad 313-358$

628 Grotzinger, J.P., Watters, W.A. and Knoll, A.H. 2000. Calcified metazoans in

629 thrombolite-stromatolite reefs of the terminal Proterozoic Nama Group, Namibia.

$630 \quad$ Paleobiology, 26: 334-359.

631 Grotzinger, J.P., Adams, E.W., Schröder, S., 2005. Microbial-metazoan reefs of the

632 terminal Proterozoic Nama Group (c. 550-543 Ma), Namibia, Geological

633 Magazine, 142: 499-517. 
634 Halevy, I. and Bachan, A. 2017. The geologic history of seawater pH. Science, 355:

635

636

637

638

639

640

641

642

643

644

645

646

647

648

649

650

651

$\begin{array}{rr}652 & \text { Kennard, J.M. 1988 } \\ 653 & \text { western New } \\ 654 & \text { Kennard, J.M. and J } \\ 655 & \text { of microbial }\end{array}$

$\begin{array}{rr}652 & \text { Kennard, J.M. 1988 } \\ 653 & \text { western New } \\ 654 & \text { Kennard, J.M. and J } \\ 655 & \text { of microbial }\end{array}$

$\begin{array}{rr}652 & \text { Kennard, J.M. } 1988 \\ 653 & \text { western New } \\ 654 & \text { Kennard, J.M. and J } \\ 655 & \text { of microbial }\end{array}$

$\begin{array}{rr}652 & \text { Kennard, J.M. } 1988 \\ 653 & \text { western New } \\ 654 & \text { Kennard, J.M. and J } \\ 655 & \text { of microbial }\end{array}$

656 Kepper, J.C., 1974. Antipathetic relation between Cambrian trilobites and stromatolites.

657

Bulletin of the American Association of Petreoleum Geologists, 58: 141-143 
658 Knight, I. and James, N.P. 1987. The Stratigraphy of the Lower Ordovician St-George

659 Group, Western Newfoundland - the Interaction between Eustasy and Tectonics.

660 Canadian Journal of Earth Sciences, 24: 1927-1951.

661 Knight, I. Azmy, K. Boyce, W.D. and Lavoie, D. 2008. Tremadocian carbonate rocks of

662 the Lower St. George Group, Port au Port Peninsula, western Newfoundland:

663 Lithostratigraphic setting of diagenetic, isotopic, and geochemistry studies,

$664 \quad$ Current Research of Newfoundland and Labrador Department of Natural

665 Resources Geological Survey, 08-1: 115-149.

666 Knoll, A. H. and Swett, K. 1990. Carbonate deposition during the late Proterozoic Era: an 667 example from Spitsbergen. American Journal of Science, 290A: 104-132.

668 Lee, J.-H. Chen, J. and Chough, S. K. 2015. The middle-late Cambrian reef transition and 669 related geological events: A review and new view. Earth-Science Reviews, 145: $670 \quad 66-84$.

671 Lewis, S. M. 1986. The role of herbivorous fishes in the organization of a Caribbean reef 672 community, Ecological Monographs, 56: 183-200.

673 Levesque, R.J. 1977. Stratigraphy and sedimentology of Middle Cambrian to Lower

$674 \quad$ Ordovician shallow water carbonate rocks, western Newfoundland. Masters

675 thesis, Memorial University, St. John, 276 pp.

676 LoDuca, S.T., Bykova, N., Wu, M., Xiao S. and Zhao, Y. 2017. Seaweed morphology

677 and ecology during the great animal diversification events of the early Paleozoic:

678 A tale of two floras, Geobiology 15: 588-616.

679 Lukasik, J. J. and James, N. P. 2003. Deepening-upward subtidal cycles, Murray Basin, 680 south Australia, Journal of Sedimentary Research, 73: 653-671. 
681 Mcintyre, I. G. Reid, R. P. Steneck, R. S. 1996. Growth history of stromatolites in a

682 Holocene fringing reef, Stocking Island, Bahamas. Journal of Sedimentary

683 Research, 66: 231-242.

684 Montanez, I. P. and Osleger, D. A. 1993. Parasequence Stacking Patterns, Third-Order

685 Accommodation Events, and Sequence Stratigraphy of Middle to Upper

686 Cambrian Platform Carbonates, Bonanza King Formation, Southern Great Basin.

687 In: Carbonate Sequence Stratigraphy: Recent Developments and Applications

688 (Eds R. G. Loucks and J. F. Sarg), AAPG Memoir, pp. 305-326.

689 Monty C. L. V. 1973. Precambrian background and Phanerozoic history of stromatolitic

690 communities, an overview. Annales de la Societé Geologique de Belgique,

$691 \quad 96: 585-624$

692 Myrow, P. W. Taylor, J. F. Runkel, A. C. and Ripperdan, R. L. 2012. Mixed

693 siliciclastic-carbonate upward-deepening cycles of the upper Cambrian inner

694 detrital belt of Laurentia. Journal of Sedimentary Research, 82: 216-231.

695 Peters, S. E. Husson, J. M. and Wilcots, J. 2017. The rise and fall of stromatolites in

$696 \quad$ shallow marine environments. Geology, doi:10.1130/G38931.1

697 Pratt, B.R. 1980. Algal-Metazoan Bioherms of Lower Ordovician Age - St-George

698 Group, Western Newfoundland. AAPG Bulletin-American Association of

$699 \quad$ Petroleum Geologists, 64: 767-768.

700 Pratt, B.R. and James, N.P. 1982. Cryptalgal-metazoan bioherms of Early Ordovician age

701 in the St-George Group, western Newfoundland. Sedimentology, 29: 543-569.

702 Pruss, S. B., Finnegan, S., Fischer, W. W., and Knoll, A. H., 2010, Carbonates in

703 skeleton-poor seas: New insights from Cambrian and Ordovician strata of

704 Laurentia, Palaios, 25: 73-84 
705 Pruss, S. B., and Clemente, H., 2011. Assessing the role of skeletons in Early Paleozoic

706 carbonate production: Insights from Cambro-Ordovician strata, western

$707 \quad$ Newfoundland, In: Quantifying the evolution of early life: Numerical and

708 technological approaches to the study of fossils and ancient ecosystems, (Eds

709 Laflamme, M., Schiffbauer, J. D., and Dornbos, S. Q.), pp. 161-183, Topics in

$710 \quad$ Geobiology, Springer, Berlin.

711 Pruss, S. B., Clemente, H., and Laflamme, M., 2012. Early Cambrian archaeocyathan

712 reefs of the Forteau Formation, southern Labrador, as a locus for skeletal

713 carbonate production, Lethaia, 45: 401-410.

714 Riding, R. 2000. Microbial carbonates; the geological record of calcified bacterial-algal

715 mats and biofilms. Sedimentology, 47: 179-214.

716 Riding, R. 2005. Phanerozoic reefal microbial carbonate abundance: Comparisons with

717 metazoan diversity, mass extinction events, and seawater saturation state. Revista

718 Española de Micropaleontología, 37: 23-39.

719 Riding, R. and Liang, L. 2005. Geobiology of microbial carbonates: metazoan and

720 seawater saturation state influences on secular trends during the Phanerozoic.

721 Palaeogeography, Palaeoclimatology, Palaeoecology, 219: 101-115.

722 Risworth, G. M. Perissinotti, R. Bird, M. S. Strydom, N. A. Peer, N. Miranda, N. A. F.

723 Raw, J. L. 2017. Non-reliance of metazoans on stromatolite-forming microbial

724 mats as a food resource. Scientific Reports, 7: 42614

725 Rowland, S.M. and Shapiro, R.S. 2002. Reef patterns and environmental influences in the

726 Cambrian and earliest Ordovician. In: Phanerozoic Reef Patterns (Eds W.

727 Kiessling, E. Flügel and J. Golonka). Society of Economic Paleontolgists and

728 Mineralogists Special Volume, Tulsa pp. 95-128. 
729 Saltzman, M.R., Cowan, C.A., Runkel, A.C., Runnegar, B., Stewart, M.C. and Palmer,

730 A.R. 2004. The Late Cambrian SPICE event and the Sauk II-Sauk III regression:

731 New evidence from Laurentian basins in Utah. Iowa, and Newfoundland. Journal $732 \quad$ of Sedimentary Research, $74: 366-377$.

733 Seilacher, A., 1999. Biomat-related lifestyles in the Precambrian, Palaios, 14: 86-93.

734 Semikhatov, M. A. and Raaben, M. E. 1996. Dynamics of the global diversity of

735 Proterozoic stromatolites. Article II: Africa, Australia, North America, and

736 general synthesis. Stratigraphic Geologic Correlation, 4: 26-55.

737 Shapiro, R.S. and Awramik, S.M. 2006. Favosamaceria cooperi new group and form: A

738 widelydispersed, time-restricted thrombolite. Journal of Paleontology, 80: 411-

$739 \quad 422$.

740 Shapiro, R.S. and Rigby, J.K. 2004. First occurrence of an in situ anthaspidellid sponge

741 in a dendrolite mound (Upper Cambrian; Great Basin, USA). Journal of

$742 \quad$ Paleontology, 78: 645-650.

743 Tarhan, L. G., Planavsky, N. J., Laumer, C. E., Stolz, J. F., Reid, R. P., 2013. Microbial

744 mat controls on infaunal abundance and diversity in modern marine microbialites,

$745 \quad$ Geobiology, 11: p. 485-497.

746 Taylor, P. D. and Wilson, M. A. 2003. Paleoecology and evolution of marine hard $747 \quad$ substrate communities. Earth-Science Reviews, 62: 1-103.

748 Theisen, C.H. and Sumner, D.Y. 2016. Thombolite facies and fabrics:Influences of

749 diverse mcorbial and metazoan processes on Cambrian thrombolite variability in

750 the Great Basin, California and Nevada. Sedimentology 63: 2217-2252.

751 Topper, T.P., Strotz, L.C., Skovsted, C.B. and Holmer, L.E. 2017. Do brachiopods show 752 substrate-related phenotypic variation? A case study from the Burgess Shale. 
Palaeontology, 60: 269-279.

754 Trotter, J.A., Williams, I.S., Barnes, C.R., Lecuyer, C. and Nicoll, R.S. 2008. Did cooling oceans trigger Ordovician biodiversification? Evidence from conodont thermometry. Science, 321: 550-554.

757 Van Wagoner J.C., Posamentier, H. W., Mitchum, R.M., Vail, P. R., Sarg, J. F., Loutit, T. S., and Hardenbol, J., 1988, An overview of the fundamentals of sequence stratigraphy and key definitions, In Sea-Level Changes: An Integrated Approach (eds. Wilgns, C.K. Hastings, B.S.,Kendall, C.G.St.C. Posamentier, H.W. Ross,

Vermeij, M. J. A. Mooreselaar, I., v. Engelhard, S. Hörnlein, C. Vonk, S. M. Visser, P. Van Wagoner J.C., Mitchum, R.M., Campion, K.M., Rahmanian V.D., 1990, Siliciclastic C.A., and Van Wagoner, J.C.). SEPM Special Publication 42: 9-45. Sequence Stratigraphy in Well Logs, Cores and Outcrops: American Association of Petroleum Geologists, Methods in Exploration Series 7: 55 pp.

M. 2010. The effects of nutrient enrichment and herbivore abundance on the ability of turf algae to overgrow coral in the Caribbean. PLOS ONE: 5: e14312.

Vinn, O. 2017. Early symbiotic interactions in the Cambrian. Palaios, 32: 213-237.

Walter, M.R. and Heys, G.R. 1985. Links between the rise of the Metazoa and the decline of stromatolites. Precambrian Research, 29: 149-174.

Westrop, S.R. 1992. Upper Cambrian (Marjuman-Steptoean) Trilobites from the Port Au Port Group, Western Newfoundland. Journal of Paleontology, 66: 228-255.

Wray J.J. 1977. Calcareous Algae. Elsevier, Amsterdam, 185 pp.

Wright, P. V. and Cherns, L. 2016. How fas did feedback between biodiversity and early diagenesis affect the nature of Early Palaeozoic sea floors. 753-765. Palaeontology, 59: 753-765. 
777 Zapata, F., Wilson, N.G., Howison, M., Andrade, S.C.S., Jörger, K.M.et al. 2014.

$778 \quad$ Phylogenomic analyses of deep gastropod relationships reject Orthogastropoda.

$779 \quad$ Proceedings of the Royal Society B 281, 20141739.

780 Zhang, Y., Li, Q., Li, Y., Kiessling, W. and Wang, J. 2016. Cambrian to Lower

781 Ordovician reefs on the Yangtze Paltform, South China, and their controlling

782 factors. Facies 62: doi: 10.1007/s10347-016-0466-8.

783 Zeebe, R. E., and Westbroek, P., 2003, A simple model for the $\mathrm{CaCO}_{3}$ saturation state of

784 the ocean: The "Strangelove", the "Neritan", and the "Cretan" ocean:

785 Geochemistry, Geophysics, Geosystems, 4: 1-26

786

$787 \quad$ Figures

788 Figure 1: Locality map showing the Port au Port Peninsula in southwestern

789 Newfoundland, Canada. The Boat Harbour Formation crops out along the eastern part of

790 the south-facing shore of the peninsula. Cambro-Ordovician strata extend along two arms

791 of an anticline on this southern shore, and examined sections are noted. Geologic map

792 modified from Conliffe et al., (2009).

793

794 Figure 2: A) Stratigraphic column of the Port au Port and St. George groups. Note

795 microbial build-ups in the Upper Cambrian Campbell's Member and Lower Ordovician

796 Watts Bight Formation. B) Detailed stratigraphy of the $\sim 12-\mathrm{m}$ succession of stacked

797 parasequences preserved in the Boat Harbour Formation. Basal portion of the section was

798 covered, and only $\sim 2 \mathrm{~m}$ of the $2.5 \mathrm{~m}$-thick bioturbated bed are shown at the top. Arrows

799 indicate thickening-upward parasequences that contain microbial build ups.

800 
801 Figure 3: Stromatolites and associated bedding features from the Boat Harbour

802 Formation. A) Low relief domal stromatolites in the lowermost parasequences (note

803 hammer for scale). B) Columnar and pseduocolumnar stromatolites in peritidal facies in

804 lower half of the section; C) Mudcracks; D) Columnar stromatolites accreting on a

805 surface of thinly bedded micrite. Note orange pods of chert. E) Pink, lightly silicified

806 ooids associated with stromatolites that directly underlie the thrombolite mounds; F)

807 Chert-rich horizon marking exposure surface.

808

809 Figure 4: Boat Harbour thrombolites. A) Large domal stromatolites and overlying

810 thrombolites of PAR 9; B) Thrombolite mound. Note discrete edges of mound and

811 distinct renalcid fabric within mound. Lower third of photo shows oolitic stromatolites

812 below thrombolite. Measuring tape shows $30 \mathrm{~cm}$. C) Close up image of thrombolite

813 showing clotted fabric.

814

815 Figure 5: Metazoan records in upper parasequences. A) Skeletal material in beds

816 overlying thrombolite mounds. Gastropods and brachiopods are shown, among other

817 invertebrate shell hash. $10 \mathrm{~cm}$ scale bar; B, D) Bedding plane showing Thalassinoides

818 traces; gastropods visible in B. C) Bioturbated laminated beds in uppermost part of

819 measured section. $10 \mathrm{~cm}$ scale bar.

820

821 Figure 6: Petrographic images of selected facies, Boat Harbour Formation (A-E) and

822 Campbell's Member (F). A) Silicified and partially dissolved ooids from the stromatolitic

823 horizon below the thrombolites; B) Peloidal laminations preserved in a stromatolite; C) 
824 Clotted, renalcid fabric in a thrombolite; D) and E) Peloidal fabric and skeletal material

825 in thrombolites; F) Echinoderm plates in a dendrolitic thrombolite.

826

827 Figure 7: Point counts of microbialites showing percent fossil material from the

828 Cambrian Port au Port and Ordovician St. George groups, western Newfoundland, and

829 the middle Cambrian Carrara Formation near Death Valley National Park, California.

830 Circles indicate each slide counted, and diamonds show the average for each category.

832 Figure 8: Other Cambrian and Lower Ordovician microbial build ups from the Port au

833 Port and St. George groups. A) Green Head reef complex, Lower Ordovician Watts Bight

834 Formation; B) Favosamaceria cooperi from the Watts Bight Formation; C) Dendrolitic

835 thrombolite from the Furongian (upper) Cambrian Campbells' Member; D) and E)

836 Laterally-linked columnar stromatolites from the Campbell's Member. Scale is $15 \mathrm{~cm}$ in

837 E.

838

839 Table 1: Points counted for all thin sections examined from the Cambrian Port au Port

840 and Ordovician St. George groups, Newfoundland and middle Cambrian Carrara

841 Formation, California. The following abbreivations are used: microbial is microbial

842 carbonate, trilo is trilobite, brach is brachiopod, unID fossils is unidentified fossils, and

843 echino is echinoderm. 


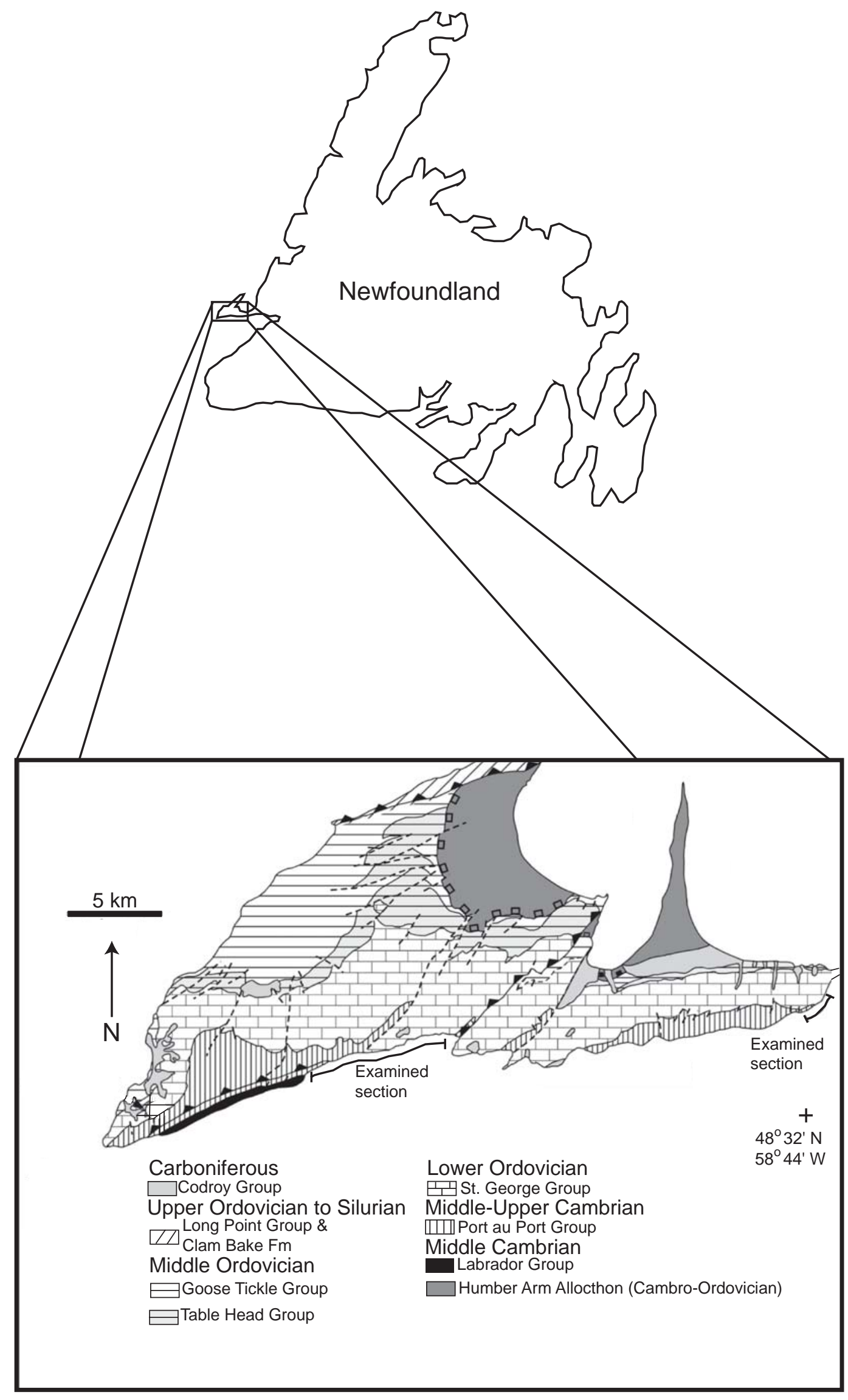

Fig. 1 


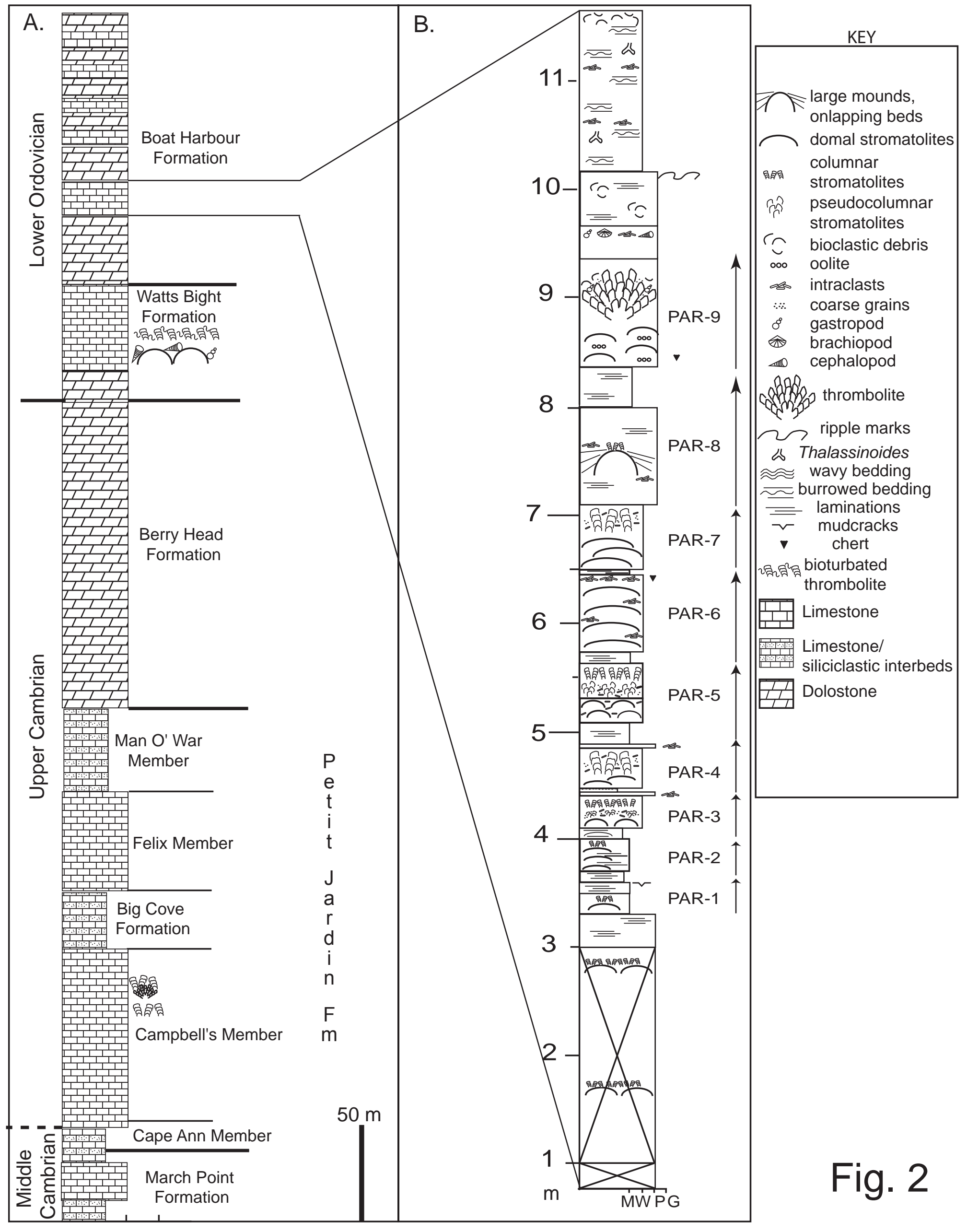




\section{A

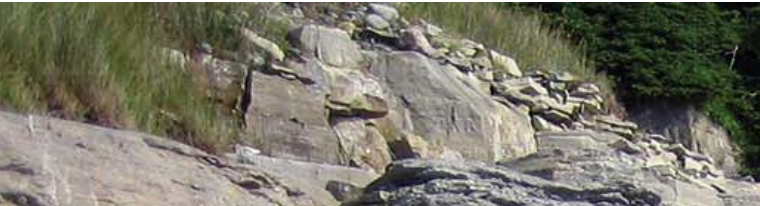 \\ $x \rightarrow-3+\leq$}

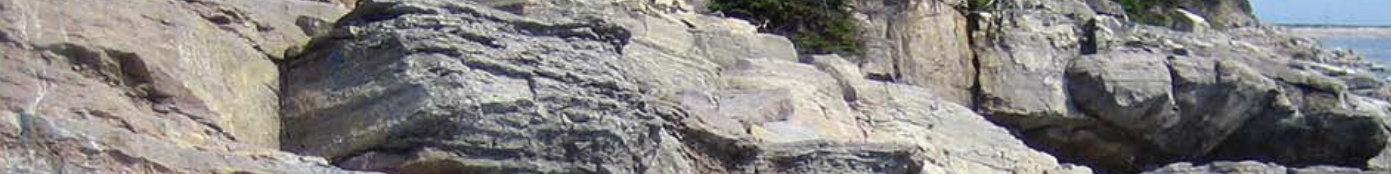

1.

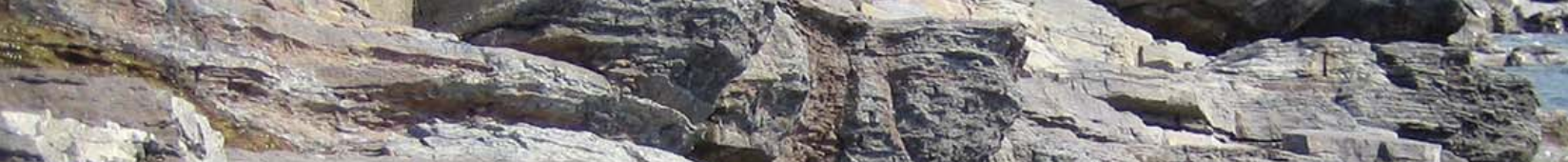

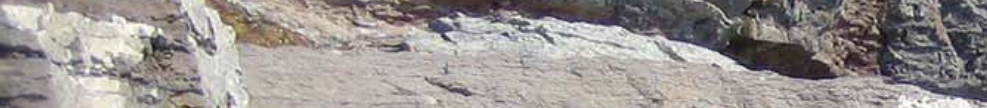

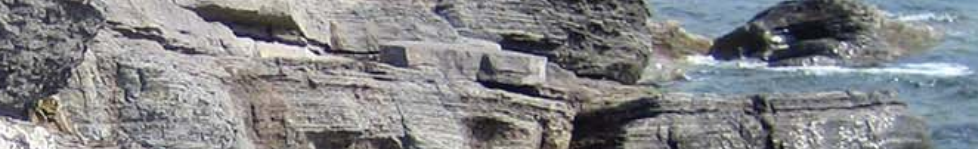

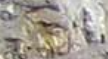

2.

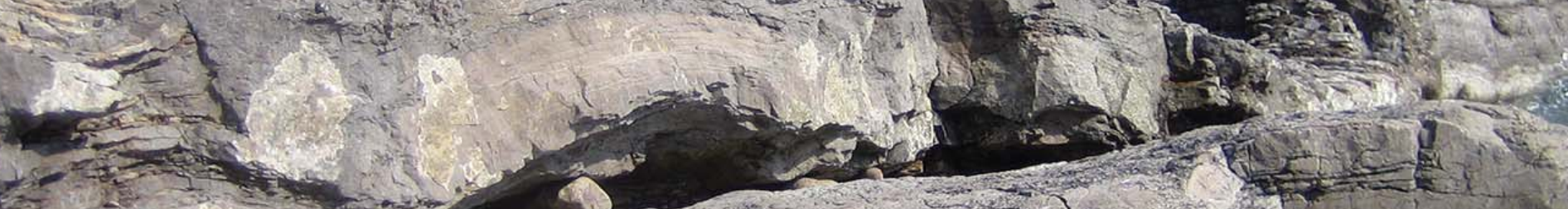

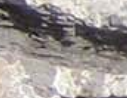

$-$

$x=$

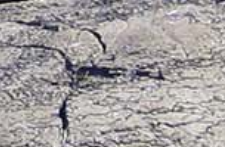

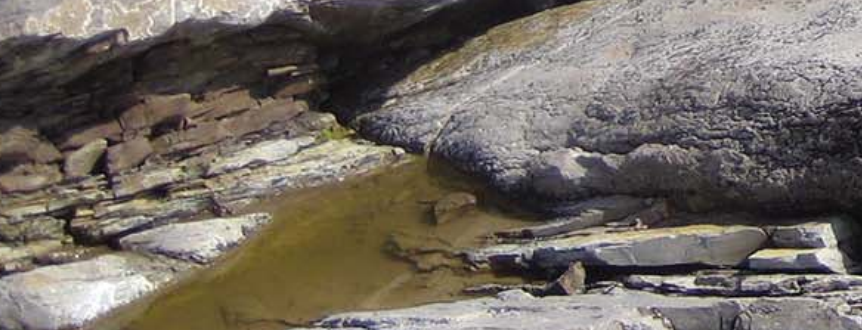
paran.

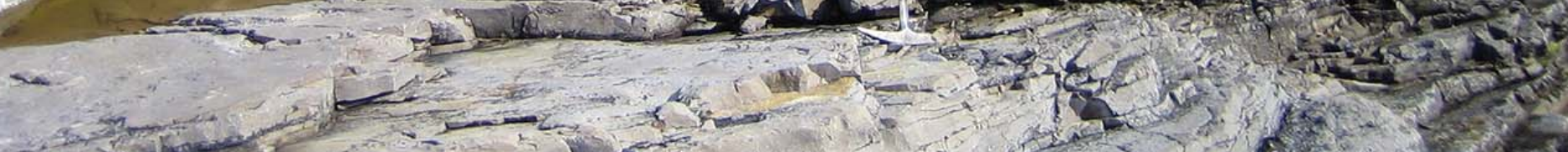

\section{B}

(9)

B

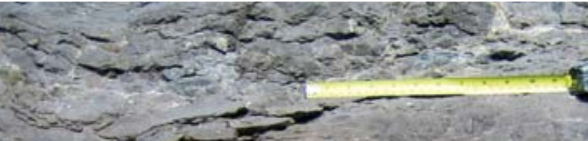

-rysteris

- $x-2 x$

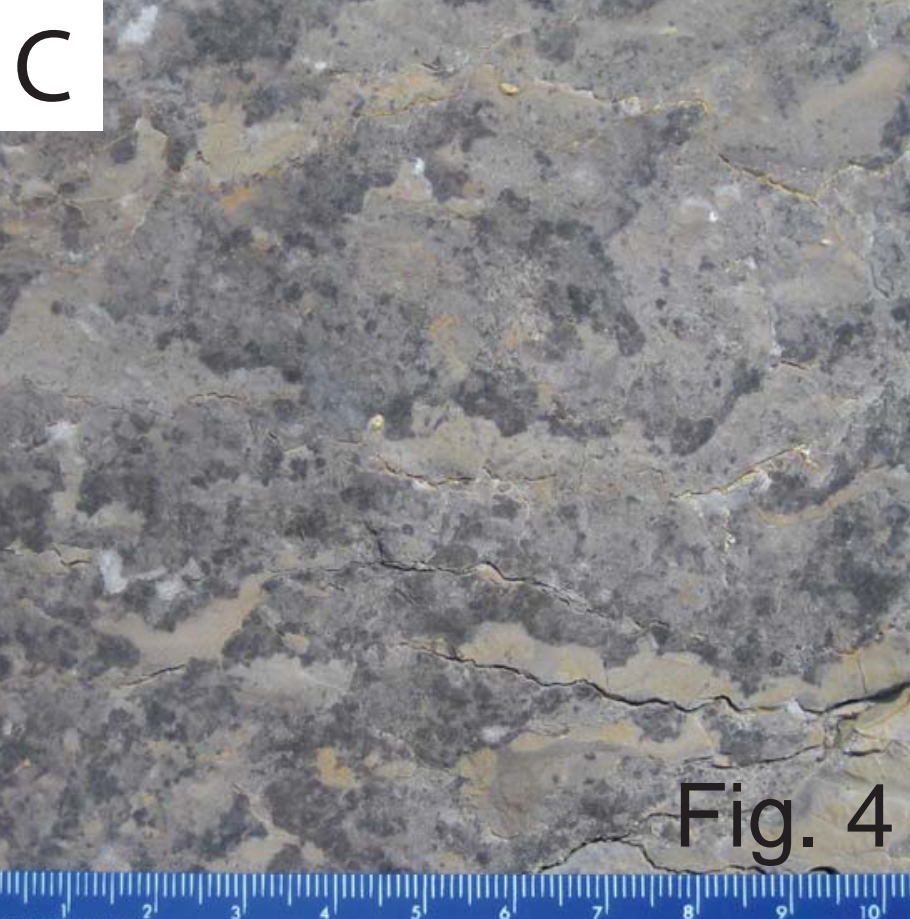



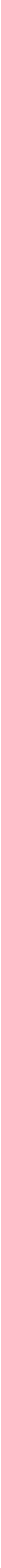


\section{A}

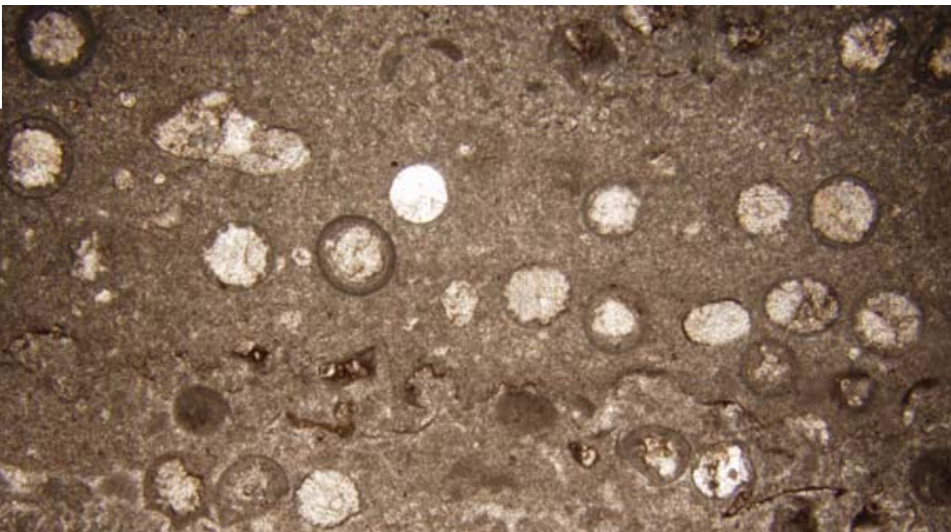

$p=7000$

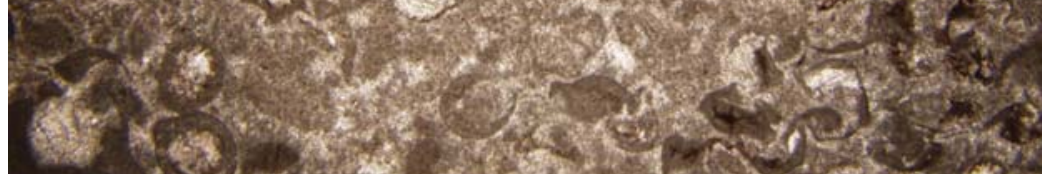

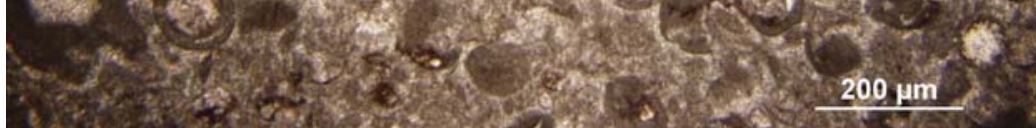

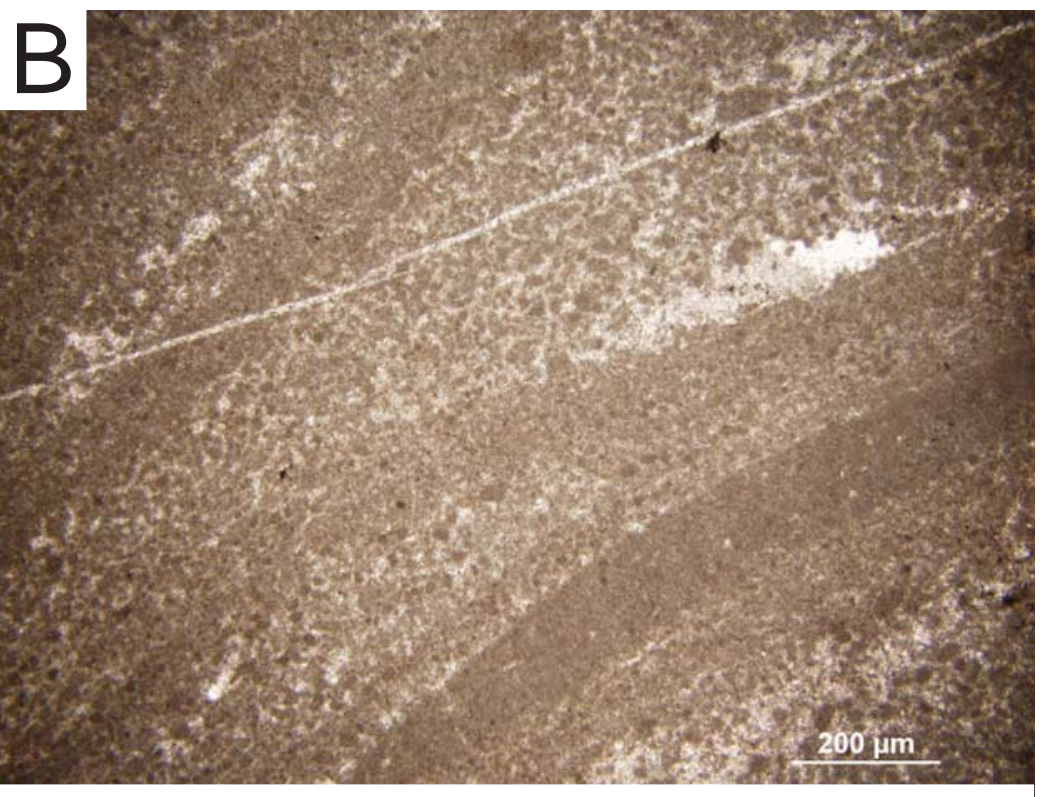

\section{C}

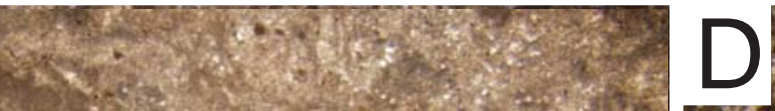

D

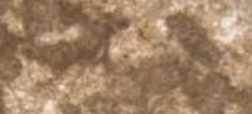

1. 8

60463
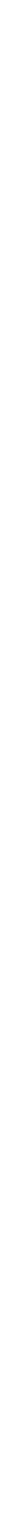


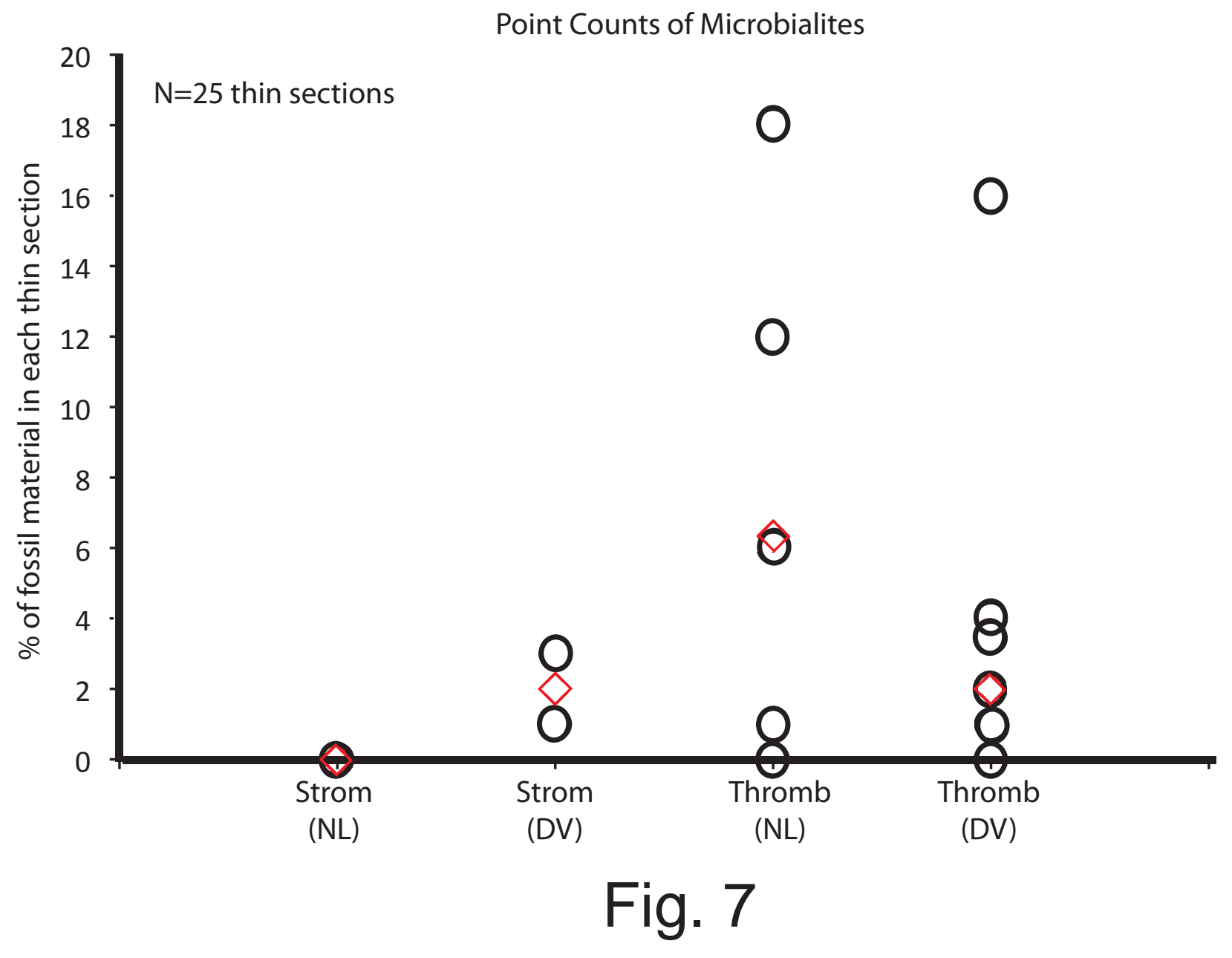



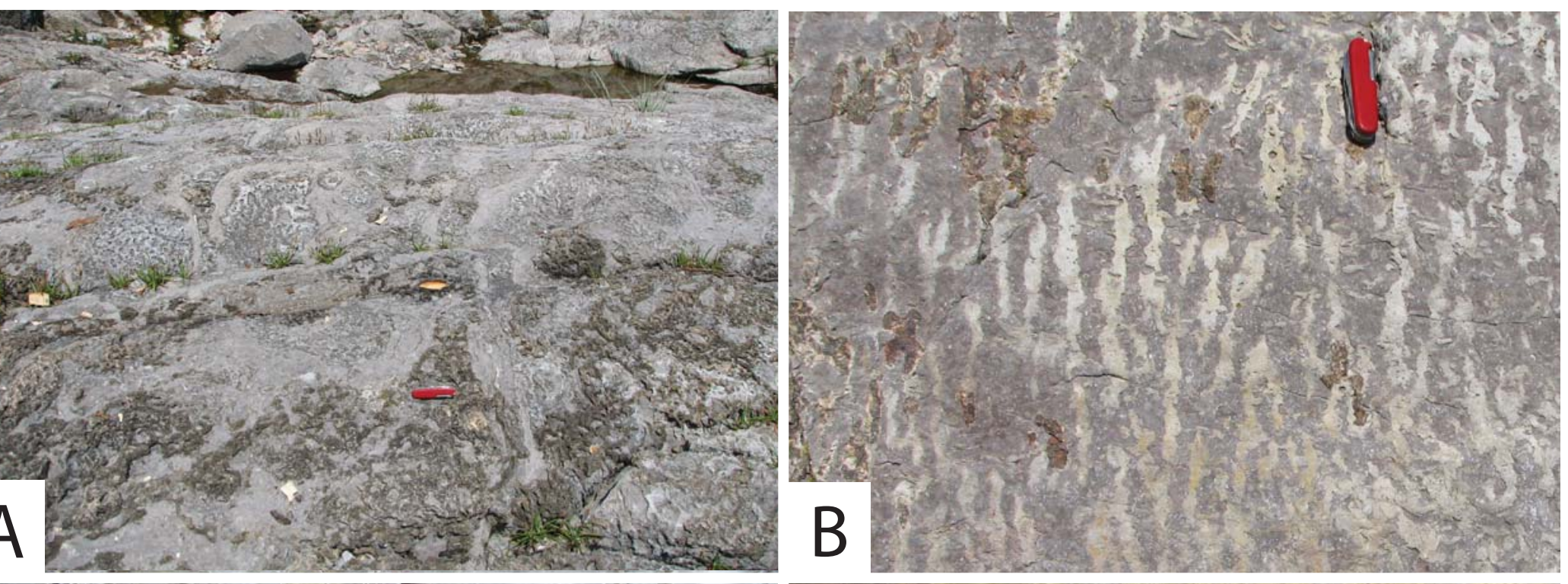

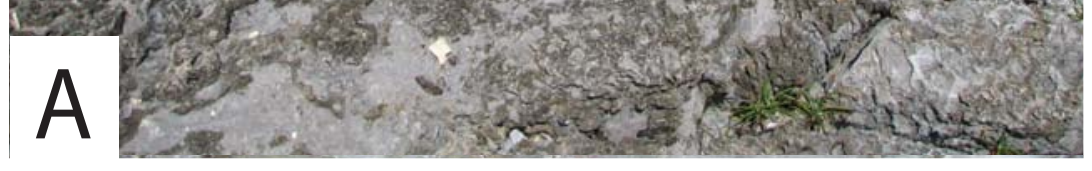
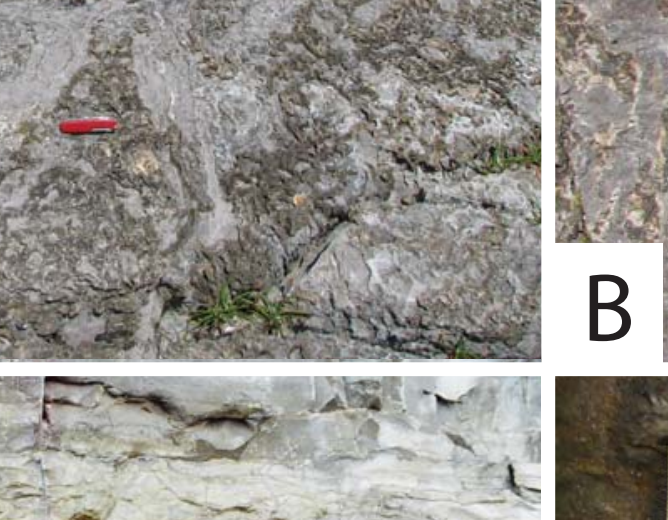

1

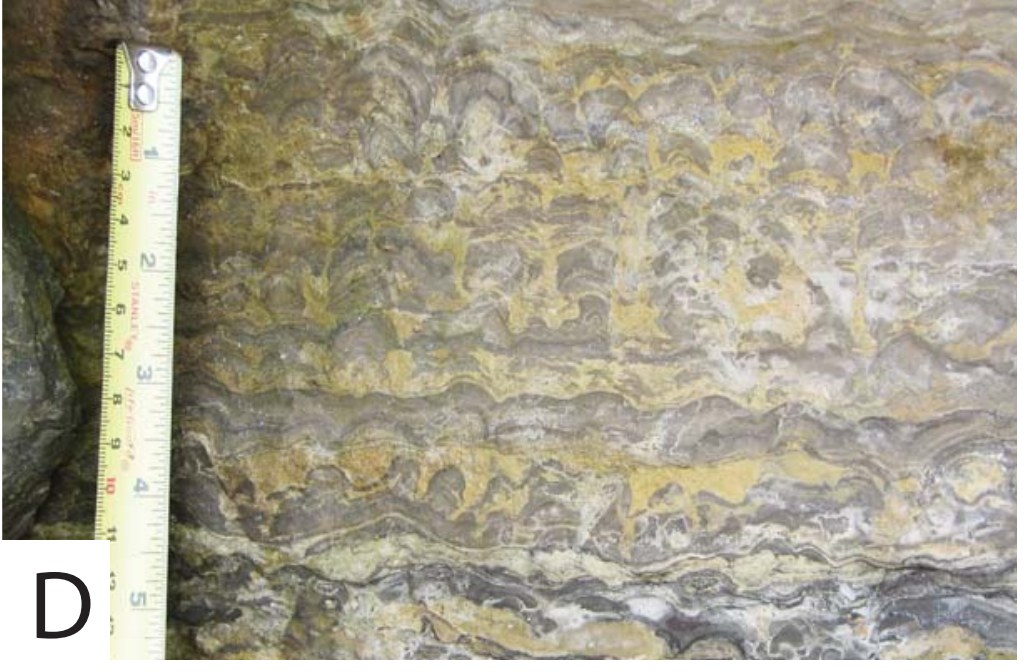

6
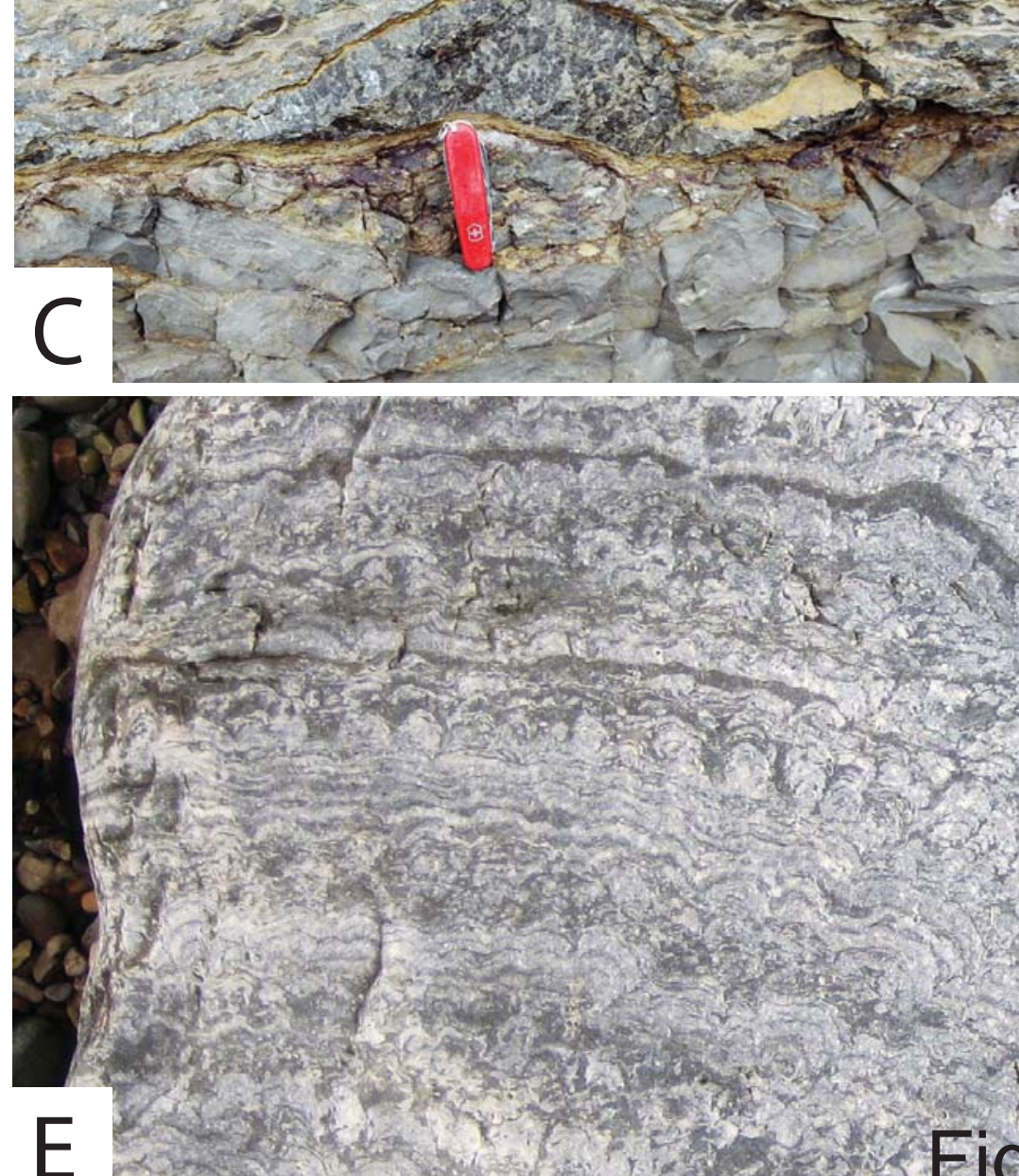

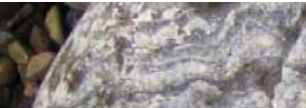

sose

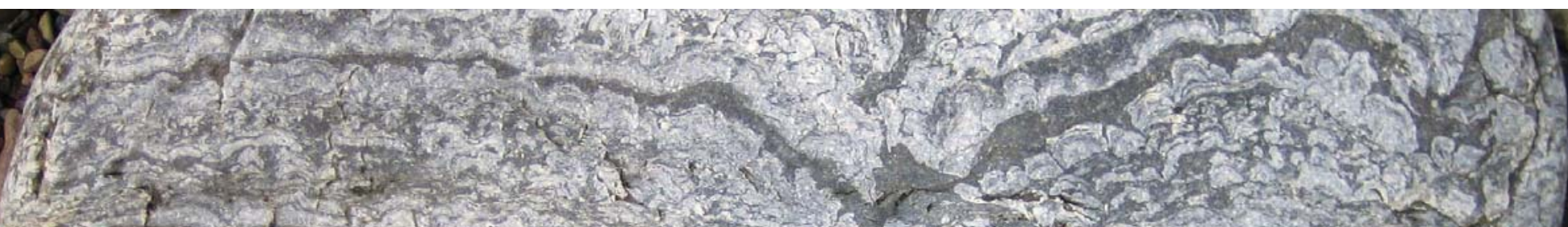

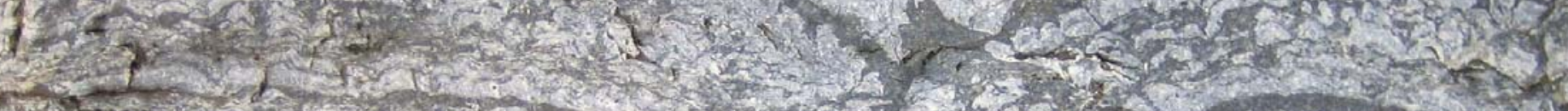
1.7.

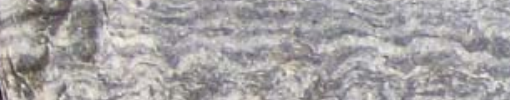

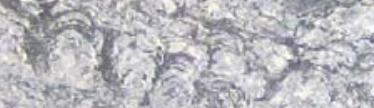

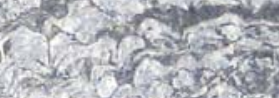

$\mathrm{x}^{3} \mathrm{x}$ $5 \times$

in

sis 31

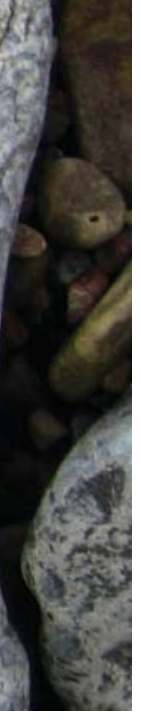




\begin{tabular}{|c|c|c|c|c|c|c|c|c|c|c|c|}
\hline & micrite & microbial & ooid & ostracod & mollusc & trilo & brach & $\begin{array}{l}\text { unID } \\
\text { fossil }\end{array}$ & echino & other & TOTAL \\
\hline $\begin{array}{l}\text { NL strom } \\
\text { CMCC-20 }\end{array}$ & 66 & 119 & 0 & 0 & 0 & 0 & 0 & 0 & 0 & 15 & 200 \\
\hline $\begin{array}{l}\text { NL strom } \\
\text { MF-41-THB }\end{array}$ & 105 & 90 & 0 & 0 & 0 & 0 & 0 & 0 & 0 & 5 & 200 \\
\hline $\begin{array}{l}\text { NL strom } \\
\text { MF-42-TH }\end{array}$ & 93 & 101 & 0 & 0 & 0 & 0 & 0 & 0 & 0 & 6 & 200 \\
\hline $\begin{array}{l}\text { NL strom } \\
\text { BH-MI-5 }\end{array}$ & 24 & 155 & 0 & 0 & 0 & 0 & 0 & 0 & 0 & 21 & 200 \\
\hline $\begin{array}{l}\text { NL strom } \\
\text { BH-MI-4B }\end{array}$ & 43 & 136 & 0 & 0 & 0 & 0 & 0 & 0 & 0 & 21 & 200 \\
\hline $\begin{array}{l}\text { NL strom } \\
\text { MF-48 }\end{array}$ & 132 & 50 & 4 & 0 & 0 & 0 & 0 & 0 & 0 & 14 & 200 \\
\hline $\begin{array}{l}\text { NL strom } \\
\text { BH-120A }\end{array}$ & 101 & 75 & 16 & 0 & 0 & 0 & 0 & 0 & 0 & 8 & 200 \\
\hline $\begin{array}{l}\text { NL strom } \\
\text { CM-30 }\end{array}$ & 39 & 123 & 1 & 0 & 0 & 0 & 0 & 0 & 0 & 37 & 200 \\
\hline $\begin{array}{l}\text { NL Thromb } \\
\text { CMCC-18 }\end{array}$ & 0 & 156 & 0 & 0 & 0 & 0 & 0 & 0 & 0 & 44 & 200 \\
\hline $\begin{array}{l}\text { NL Thromb } \\
\text { MF-41-TH }\end{array}$ & 87 & 100 & 0 & 0 & 0 & 0 & 1 & 0 & 0 & 12 & 200 \\
\hline $\begin{array}{l}\text { NL Thromb } \\
\text { BH08-64-B2 }\end{array}$ & 126 & 58 & 0 & 0 & 1 & 0 & 0 & 0 & 0 & 15 & 200 \\
\hline $\begin{array}{l}\text { NL Thromb } \\
\text { CMCC-5 }\end{array}$ & 151 & 23 & 0 & 0 & 0 & 6 & 0 & 0 & 0 & 20 & 200 \\
\hline $\begin{array}{l}\text { NL Thromb } \\
\text { CMCC-13 }\end{array}$ & 126 & 36 & 4 & 0 & 0 & 0 & 0 & 4 & 14 & 16 & 200 \\
\hline $\begin{array}{l}\text { NL Thromb } \\
\text { CM-28-MI3 }\end{array}$ & 139 & 39 & 0 & 0 & 0 & 7 & 0 & 1 & 4 & 10 & 200 \\
\hline & 106 & 69 & 0 & 0 & 0 & 0 & 0 & 1 & 0 & 24 & 200 \\
\hline
\end{tabular}




\begin{tabular}{|c|c|c|c|c|c|c|c|c|c|c|c|}
\hline \multicolumn{12}{|l|}{$\begin{array}{l}\text { DV strom } \\
\text { EM01 49- } \\
3 \mathrm{~A}\end{array}$} \\
\hline \multicolumn{12}{|l|}{ DV strom } \\
\hline $3 B$ & 69 & 104 & 0 & 1 & 0 & 0 & 0 & 2 & 0 & 24 & 200 \\
\hline \multicolumn{12}{|l|}{ DV thromb } \\
\hline EM01 TB-A & 106 & 77 & 0 & 0 & 0 & 1 & 0 & 0 & 0 & 16 & 200 \\
\hline \multicolumn{12}{|l|}{ DV thromb } \\
\hline EM01 TB-B & 99 & 77 & 0 & 0 & 0 & 0 & 0 & 0 & 0 & 24 & 200 \\
\hline \multicolumn{12}{|l|}{ DV thromb } \\
\hline EP01 ST-BB & 63 & 126 & 0 & 0 & 0 & 1 & 0 & 0 & 0 & 10 & 200 \\
\hline \multicolumn{12}{|l|}{ DV thromb } \\
\hline EP01 ST-CB & 74 & 107 & 1 & 0 & 0 & 3 & 0 & 1 & 0 & 14 & 200 \\
\hline \multicolumn{12}{|l|}{ DV thromb } \\
\hline EP01 ST-CD & 73 & 101 & 0 & 0 & 0 & 1 & 0 & 0 & 1 & 24 & 200 \\
\hline \multicolumn{12}{|l|}{ DV thromb } \\
\hline EP01 ST-AA & 89 & 93 & 1 & 0 & 0 & 2 & 0 & 0 & 2 & 13 & 200 \\
\hline \multicolumn{12}{|l|}{ DV thromb } \\
\hline EP01 ST-FB & 78 & 97 & 0 & 0 & 0 & 0 & 0 & 0 & 1 & 24 & 200 \\
\hline \multicolumn{12}{|l|}{ DV thromb } \\
\hline EP01 ST-G & 100 & 86 & 0 & 0 & 0 & 0 & 0 & 0 & 2 & 12 & 200 \\
\hline \multicolumn{12}{|l|}{ DV thromb } \\
\hline EP01 ST-HA & 104 & 69 & 0 & 0 & 0 & 16 & 0 & 0 & 0 & 11 & 200 \\
\hline
\end{tabular}

